\title{
Paleosismolojik Üç Boyutlu Sanal Fotoğraflama Yöntemi, Örnek Çalışma: Duru-2011 Hendeği, Tuz Gölü Fay Zonu, Orta Anadolu, Türkiye
}

\author{
Paleoseismological Three Dimensional Virtual Photography Method, Case Study: Duru-2012 \\ Trench, Tuz Gölü Fault Zone, Central Anatolia, Turkey
}

\author{
Akın KÜRÇER ${ }^{1}$, Yaşar Ergun GÖKTEN² \\ ${ }^{1}$ Maden Tetkik ve Arama Genel Müdürlüğü, Jeoloji Etütleri Dairesi Başkanlığı, 06800 Çankaya, \\ Ankara,Türkiye (akin.kurcer@mta.gov.tr) \\ ${ }^{2}$ Okan Üniversitesi, Sürekli Eğitim Merkezi, Kızılay, Ankara, Türkiye \\ (ergun.gokten@okan.edu.tr)
}

$\ddot{O z Z}$

Paleosismoloji; eski depremlerin yeri, zamanı ve büyüklüğü hakkında bilgi elde etmeye çalışan bir aktif tektonik çalışma disiplinidir. Hendekli paleosismoloji çalışmaları, paleosismolojide sıkça uygulanan ve kayda değer veri sağlayan bir yöntemdir. Özellikle derin ve basamaklı hendek çalışmalarında karşılaşılan en önemli sorunlardan biri, hendek duvarlarındaki jeolojik bilgilerin okuyucuya görsel olarak aktarılmasıdır.

Bu makalede, paleosismolojik hendek çalışmaları için yeni bir fotoğraflama yöntemi olan "Paleosismolojik Üç Boyutlu Sanal Fotoğraflama Yöntemi” örnek bir uygulama ile tanıtılmıştır. Paleosismolojik Üç Boyutlu Sanal Fotoğraflama Yöntemi, sırasıyla planlama, fotoğraflama, fotoğrafların birbirine eklenmesi ve sanal tur oluşturulması olmak üzere dört aşamadan oluşmaktadır. Bu yöntem ile elde edilen sanal tur, bir hendek çalışmasının görsel olarak okuyucuya sunulmasına olanak sağlamanın ötesinde, hendek verilerinin özellikle yorumlanması aşamasında çok önemli katkılar sağlamaktadır. Paleosismolojik Üç Boyutlu Sanal Fotoğraflama Yöntemi ilk defa, Tuz Gölü Fay Zonu (Orta Anadolu, Türkiye) üzerinde yürütülen paleosismoloji çalışmalarında uygulanmıştır. Orta Anadolu Bölgesi'nin en önemli kıta içi aktif fay zonlarından biri olan TGFZ, yaklaşık 200 km uzunluğunda, KB-GD doğrultulu, aktif, sağ yanal doğrultu atım bileşenli normal bir fay zonudur. Uzunlukları 9 ile $33 \mathrm{~km}$ arasında değişen birbirine koşut veya yarı koşut fay segmentlerinden oluşan TGFZ'nun en önemli segmentlerinden biri Akhisar-Kılıç segmentidir. Bu çalışmada, Akhisar-Kılıç segmentinin orta bölümünde bir hendek kazılmıştır.

Hendek stratigrafisi, fay koluviyal kama geometrisi, fay kollarının yukarıya doğru sonlanması gibi paleosismolojik ölçütler ve ${ }^{14-C}$ yaş verileri kullanılarak yapılan değerlendirmede, Duru-2011 Hendeği'nde son 23000 yıl içerisinde üç paleosismik olay tanımlanmıştır. Diğer taraftan, Akhisar-Kılıç segmenti üzerinde yürütülen bir başka paleosismoloji çalışmasında, son 10500 yıl içerisinde iki deprem tanımlanmıştır. Aynı segment üzerindeki iki hendekten derlenen deprem verileri fay penceresi yöntemiyle değerlendirilmiş 
ve Akhisar-Kılıç segmenti için ortalama deprem tekrarlanma aralığg 10390 yıl olarak hesaplanmıştır. Akhisar-Kılıç segmenti üzerindeki yakın dönem (Geç Pleyistosen-Günümüz) düşey kayma hızı 0,034 mm/yıl olarak hesaplanmıştır. Bu değer, segmentin uzun dönem (Geç Pliyosen) düşey kayma hızı (0,046 $\mathrm{mm} / \mathrm{y} 1 \mathrm{l})$ ile oldukça uyumludur.

Anahtar Kelimeler: ${ }^{14} \mathrm{C}$, hendek, paleosismoloji, paleosismolojik üç boyutlu sanal fotoğraflama yöntemi, Tuz Gölü fay zonu.

\section{ABSTRACT}

Paleoseismology is an active tectonic discipline that tries to obtain information about the location, time and magnitude of paleoearthquakes by using geological and geomorphological data. Paleoseismic trenching is the most important method that is frequently used in paleoseismology and provides considerable data. One of the most important problems encountered especially in deep and benched paleoseismological trench works is the visual representation of the trench stratigraphy and structure to the reader.

In this paper, "Paleoseismological Three Dimensional Virtual Photography Method", a new photographic method for paleoseismology, is presented with a case study. Paleoseismological Three Dimensional Virtual Photography Method consists of four stages which are respectively: planning, photographing, stitching and constraction of virtual tour.

Paleoseismological Three Dimensional Virtual Photography Method has been applied for the first time during the paleoseismological studies carried out on the Tuz Gölü Fault Zone (Central Anatolia, Turkey). The Tuz Gölü Fault Zone (TGFZ) is one of the most important intra-continental active fault zones in the Central Anatolian Region. TGFZ is an approximately $200 \mathrm{~km}$-long, NW-SE trending, active normal fault zone with a right lateral strike-slip component. The Akhisar-Kllıç segment is one of the most important segments of TGFZ which is composed of fault segments parallel or sub-parallel to each other and with lengths varying between 9 and $33 \mathrm{~km}$. In this study, a paleoseismic trench (Duru-2011) has been excavated on the middle section of Akhisar-Kılıç segment.

As a result of the evaluation carried out making use of paleoseismological criteria such as trench microstratigraphy, geometry of fault colluvial wedge, upward termination of fault strands, and ${ }^{14} \mathrm{C}$ age data, three paleoseismic events were described within the Duru-2011, which occurred in the last 23000 years. On the other hand, in the last 10500 years two paleoseismic events has been described within the another paleoseismological study. Earthquake data collected from the two trenches on the same segment were evaluated by "fault window method". And averagely earthquake recurrence period of Akhisar-Kilıç segment was calculated as 10390 year. Short time (Late Pleistocene - Recent) annual vertical slip rate of Akhisar-Kllıç segment was calculated as 0,034 mm/year. This value is well consistent with long term (Late Pliocene) vertical geological slip rate $(0,046 \mathrm{~mm}$-year) of segment.

Key words: ${ }^{14-} \mathrm{C}$, paleoseismology, paleoseismological three dimensional virtual photography method, trench, Tuz Gölü fault zone. 


\section{GíRİş}

Depremsellik açısından tehlike içeren bölgelerde, deprem tehlike analizlerinin doğru ve güvenilir biçimde yapılabilmesi, o bölgedeki aktif fayların deprem davranış biçimlerinin belirlenmesi ile mümkündür. Aktif fay; Kuvaterner'de yüzey faylanması veya deformasyonuyla sonuçlanmış büyük deprem üreten ve gelecekte yüzey faylanması veya deformasyonuna yol açabilecek büyüklükte deprem üretme potansiyeli taşıyan fay olarak tanımlanabilir. Aktif fayların deprem davranış biçimlerinin ortaya çıkartılmasında günümüzde kabul gören ve yaygın olarak kullanılan en önemli yöntem Paleosismolojidir. Paleosismoloji; jeolojik ve jeomorfolojik verilerden yararlanarak, eski depremlerin yeri, zamanı ve büyüklüğü hakkında bilgi elde etmeye çalışan bir disiplindir (McCalpin, 1996).

Paleosismolojik hendek açma yöntemi (paleoseismic trecnhing), paleosismolojide sıç̧a uygulanan ve kayda değer veriler sağlayan yöntemlerden biridir. $\mathrm{Bu}$ yöntemde, faylanma tipine bağlı olarak aktif fay izine dik ya da koşut olarak kazılan hendekler içerisinde sedimantoloji, stratigrafi ve yapısal jeoloji esaslarına göre jeolojik değerlendirmeler yapılır. Daha sonra, eski depremlerin tarihlendirilmesine olanak sağlayacak çökellerden numuneler derlenir ve uygun radyometrik yaşlandırma teknikleri kullanılarak tarihlendirilir.

Paleosismolojik hendeklerin kazı tipleri ve boyutları, çalışılan fayın özelliğine (faylanma tipi, yıllık kayma hızı, deprem tekrarlanma aralığı, her depremde meydana gelen yer değiştirme miktarı, bilinen son tarihsel depremden günümüze kadar geçen süre vb.) ve hendek sahasının fiziksel parametrelerine (yer altı su durumu, hendek çökellerinin duraylılı̆̆ Göreceli olarak daha düşük kayma hızına sahip (< $1 \mathrm{~mm} / \mathrm{y} 1 \mathrm{l})$ ve eğim atımın baskın olduğu faylarda yapılan paleosismolojik kazılar daha derin ve kapsamlı yapılmaktadır. Yer altı su seviyesinin sı̆̆ olduğu ya da hendek duvarlarının stabil olmadığı durumlarda, hendekler güvenlik açısından basamaklı ve/veya şevli kazılmaktadır.

Hendek duvarlarının temizlenmesinin ardından, hendekteki jeolojik ayrıntılar dikkate alınarak karelajlama (gridding) yapılır. Karelajlamada genellikle $1 \mathrm{~m}$ grid aralığı standart kabul edilmektedir. Karelajlamanın ardından, hendeğin görsel olarak kayıt altına alınması gerekir. Bu aşamada karşılıklı hendek duvarlarının belirli bir ölçekte loglanması ve fotoğraflanması gerekir. Loglama iki şekilde yapılabilir. Manuel loglama tekniğinde, hendek duvarlarındaki her bir karelaj genellikle 1/20 m. ölçeğinde küçültülerek çizilir ve ardından bu çizimler birleştirilerek hendek duvarının tamamina ait duvar logu elde edilir. Fotomozayik loglamasında ise hendek duvarının yeter sayıda fotoğrafı çekilir ve bilgisayar ortamında çeşitli yazılımlar kullanılarak bu fotoğraflar birleştirilir. Hendek duvarının tamamına ait bir fotomozayik oluşturulur ve loglama bu fotoğraf üzerinden yapılır. Fotomozayik loglama tekniği, çizimden kaynaklanabilecek hata oranını en aza indirme olanağı sağladığı ve hızlı bir yöntem olduğu için son yıllarda paleosismolojide sıkça kullanılmaktadır. Ancak bu yöntem, fotoğrafların birleştirilmesinde hatalara neden olduğu ve fotoğrafta bozulmalar meydana geldiği için derin ve basamaklı kazılarda yetersiz kalmaktadır. Bunlardan başka, hendek jeolojisinin nicel olarak değerlendirilebilmesi açısından, manyetik duyarlılık ölçümleri gibi bazı fiziksel ölçümlerin de yapıldığı güncel paleosismolojik çalışmalar da bulunmaktadır (Örneğin Fraser vd., 2009).

$\mathrm{Bu}$ makalede, paleosismolojik hendek çalışmaları için yeni bir fotoğraflama yöntemiöolan "Paleosismolojik Üç Boyutlu Sanal Fotoğraflama 
Yöntemi (Paleoseismological Three-Dimensional Virtual Photography Method)" yöntemi örnek bir uygulama ile tanıtılmıştır. Yöntem Dünya'da ilk defa, yazarlar tarafindan Tuz Gölü Fay Zonu (Orta Anadolu, Türkiye) üzerinde yürütülen paleosismoloji çalışmalarında (Kürçer, 2012; Kürçer ve Gökten, 2012) uygulanmıştır.

\section{TUZ GÖLÜ FAY ZONU - AKHISSAR-KILIÇ SEGMENTİ}

Afrika, Arap ve Avrasya levhaları arasındaki kıtasal çarpışmaya bağlı olarak gelişen ilerleyen deformasyon sonucunda, sağ yanal Kuzey Anadolu Fay Sistemi (KAFS), sol yanal Doğu Anadolu Fay Sistemi (DAFS) ve Ölü Deniz Fay Sistemi (ÖDFS) ile aktif bir yitim zonu olan EgeKibris dalma-batma zonu ile birbirinden ayrilan dört ana neotektonik bölge gelişmiştir. Bunlar; Doğu Anadolu sıkışma bölgesi, Kuzey Anadolu bölgesi, Batı Anadolu genişleme bölgesi ve Orta Anadolu "Ova” bölgesidir (Şengör, 1980; Şengör vd., 1985). Orta Anadolu bölgesinde, gerilme kökenli, birbirine koşut olmayan verev atımlı faylar ile sınırlı havzalar (örneğin Tuz Gölü havzası) Şengör (1980) tarafından "Ova" olarak tanımlanmış ve bu alan "Orta Anadolu Ova bölgesi" olarak isimlendirilmiştir. Şengör (1980)'e göre bu alan Batı Anadolu genişleme sisteminin doğuya doğru giderek zayıflayan bir devamı niteliğindedir. Orta Anadolu ova bölgesi aynı zamanda, diğer üç neotektonik bölge arasındaki geçiş zonunu oluşturmaktadır (Dirik ve Göncüoğlu 1996; Koçyiğit ve Beyhan 1998; Dirik 2001; Koçyiğit ve Erol 2001; Dirik ve Erol 2003; Koçyiğit ve Özacar 2003; Koçyiğit, 2005). Orta Anadolu Bölgesi'ni konu alan güncel jeodetik çalışmalara göre, bu bölgedeki baskın genişlemeli tektonik rejimin kaynağı, GB'daki Helen yitim zonundan kaynaklı hendeğin çekim kuvvetidir (Aktuğ vd., 2013).
Tuz Gölü Fay Zonu (TGFZ), Orta Anadolu Bölgesi'nin en önemli kıta içi aktif fay zonlarından biridir (Şaroğlu vd., 1992, Dirik ve Göncüoğlu, 1996, Çemen vd., 1999, Koçyiğit, 2000; Kürçer, 2012; Kürçer ve Gökten, 2012) (Şekil 1). Morfotektonik özellikleri ve büyüklükleri 5'e ulaşan deprem dişmerkezlerinin dağılımları göz önüne alındığında TGFZ halen aktiftir (Dirik ve Erol, 2000; Kürçer, 2012; Kürçer ve Gökten, 2012). TGFZ, KB'da Tuz Gölü ile GD'da Kemerhisar (Niğde) arasında KB-GD doğrultusunda uzanan, yaklaşık $200 \mathrm{~km}$ uzunluğunda, sağ yanal doğrultu atım bileşenli normal bir fay zonudur. Bu zon aynı zamanda, doğudaki normal bileşenli doğrultu atıml neotektonik rejim bölgesi ile batıdaki genişlemeli neotektonik rejim bölgesinin birbirinden ayıran bir geçiş zonudur (Koçyiğit ve Özacar, 2003).

Uzunlukları 9 ile $33 \mathrm{~km}$ arasında değişen birbirine koşut veya yarı koşut fay segmentlerinden oluşan TGFZ'nun en önemli segmentlerinden biri, jeolojik fay uzunluğu ve morfotektonik özellikleri nedeniyle Akhisar-Kılıç Segmenti'dir. 27 km uzunluğundaki Akhisar-Kılıç segmenti, TGFZ'nun orta bölümünde yer alır ve Akhisar köyü ile Hasandağ arasında $\mathrm{K} 25^{\circ}-30^{\circ} \mathrm{B}$ doğrultusunda uzanır (Şekil 2).

Şekil3'teAkhisar-Kılıç Segmenti boyunca hazırlanmış jeoloji haritası sunulmuştur. AkhisarKılıç segmenti, KB' da Akhisar köyü civarında Erken Pliyosen yaşlı Kızılkaya ignimbritlerini keser. Akhisar ile Yuva köyleri arasında Oligosen yaşlı Yassıpur formasyonu ile Kuvaterner yaşlı alüvyon yelpaze çökellerinin sınırını oluşturur, yer yer de alüvyon yelpazelerini keser. AkhisarKılıç segmenti, Yuva köyü KB'sından itibaren Hasandağ volkanitlerini keser. Yuva ile Helvadere köyleri arasında KB-GD uzanımlı elipsoidal geometrili çöküntü alanını KD'dan sınırlandıran fay, bu alanda yer yer Geç Pleyistosen - Holosen 
çökellerini de kesmektedir. Helvadere GD'sundan itibaren Kılıç sırtına kadar olan bölümde yeniden Hasandağ volkanitlerini kesen fay segmenti, Kılıç sırtı mevkiinde son bulur. Akhisar - Kılıç segmenti, Akhisar ile Yuva köyü arasında birbirine paralel dizilmiş alüvyon yelpazeleri ve çizgisel fay sarplıkları ile karakteristiktir. Bu alanda fay izi boyunca dizilmiş çok sayıda soğuk ve acı su kaynağı bulunmaktadır.

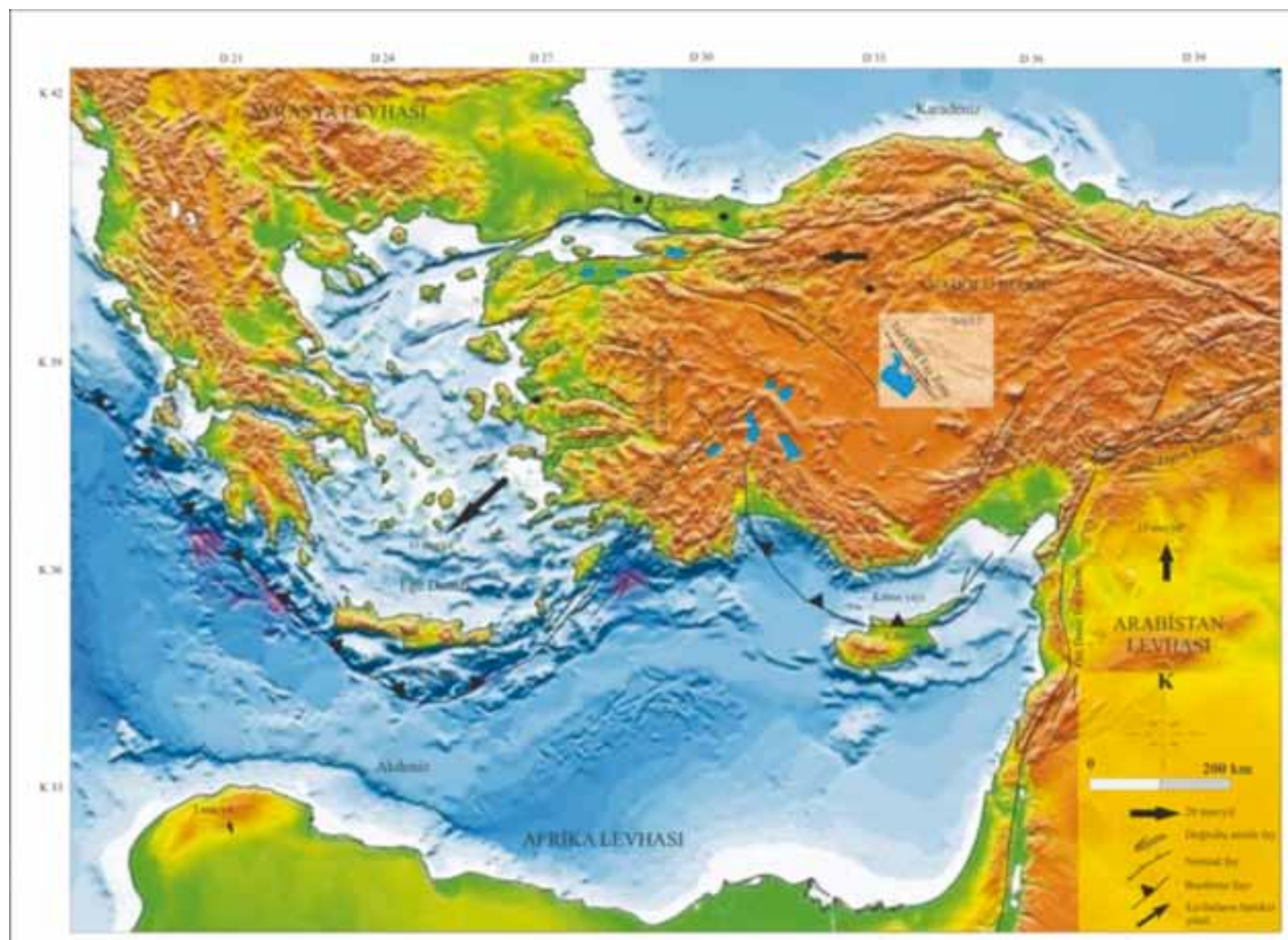

Şekil 1. Doğu Akdeniz Bölgesi’nin başlıca neotektonik unsurları ve Tuz Gölü Fay Zonu'nun konumu (Okay vd., 2000'den düzenlenmiştir; Kürçer, 2012; Kürçer ve Gökten, 2012). Siyah oklar ve rakamlar Avrasya plakasına göre göreceli levha hareket yönlerini ve GPS hızlarını göstermektedir (Reilinger vd. 2006).

Figure 1. Main neotectonic elements of Eastern Mediterranean Region and location of Tuz Gölü Fault Zone (Modified from Okay et al., 2000, as cited in Kürçer, 2012; Kürçer and Gökten, 2012). Black arrows and correponding numbers show GPS-derived plate velocities (mm-year) relative to Eurasia (Reilinger et al., 2006) 


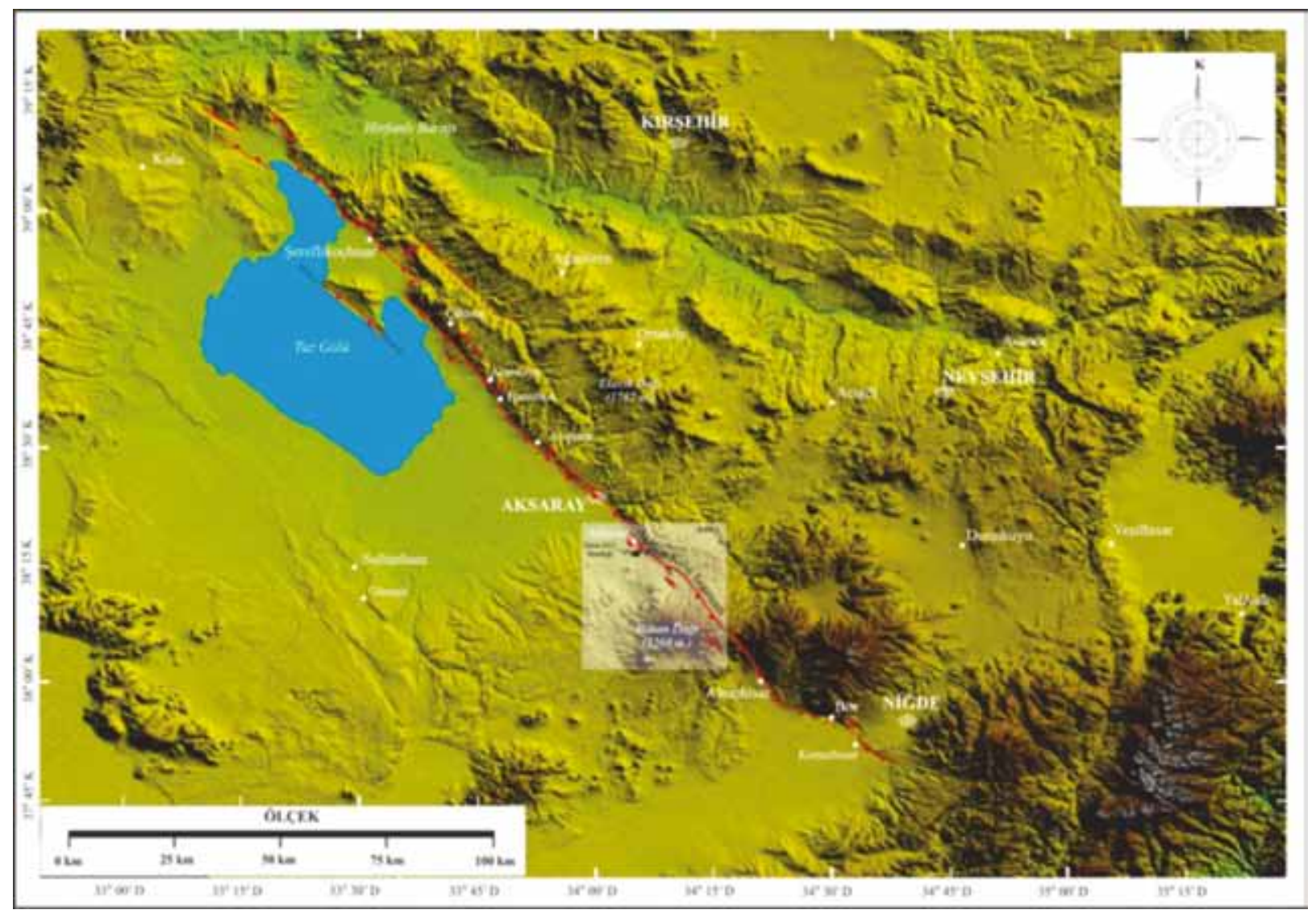

Şekil 2. Bölgeye ait Sayısal Yükseklik Modeli üzerinde Tuz Gölü Fay Zonu'nun segmentleri ve bu segmentler içerisinde Akhisar-Kılıç Segmenti ve Duru-2011 Hendeği’nin konumu (Sayısal Yükseklik Modeli için Shuttle Radar Topography Mission-SRTM verileri kullanılmıştır) (Kürçer, 2012; Kürçer ve Gökten, 2012).

Figure 2. Segments of Tuz Gölü Fault Zone and setting of Akhisar-Kllıç segment and Duru-2011 Trench on the Digital Elevation Model of the region (Shuttle Topography Mission - SRTM data were used for the Digital Elevation Model) (Kürçer, 2012, as cited in Kürçer and Gökten, 2012) 


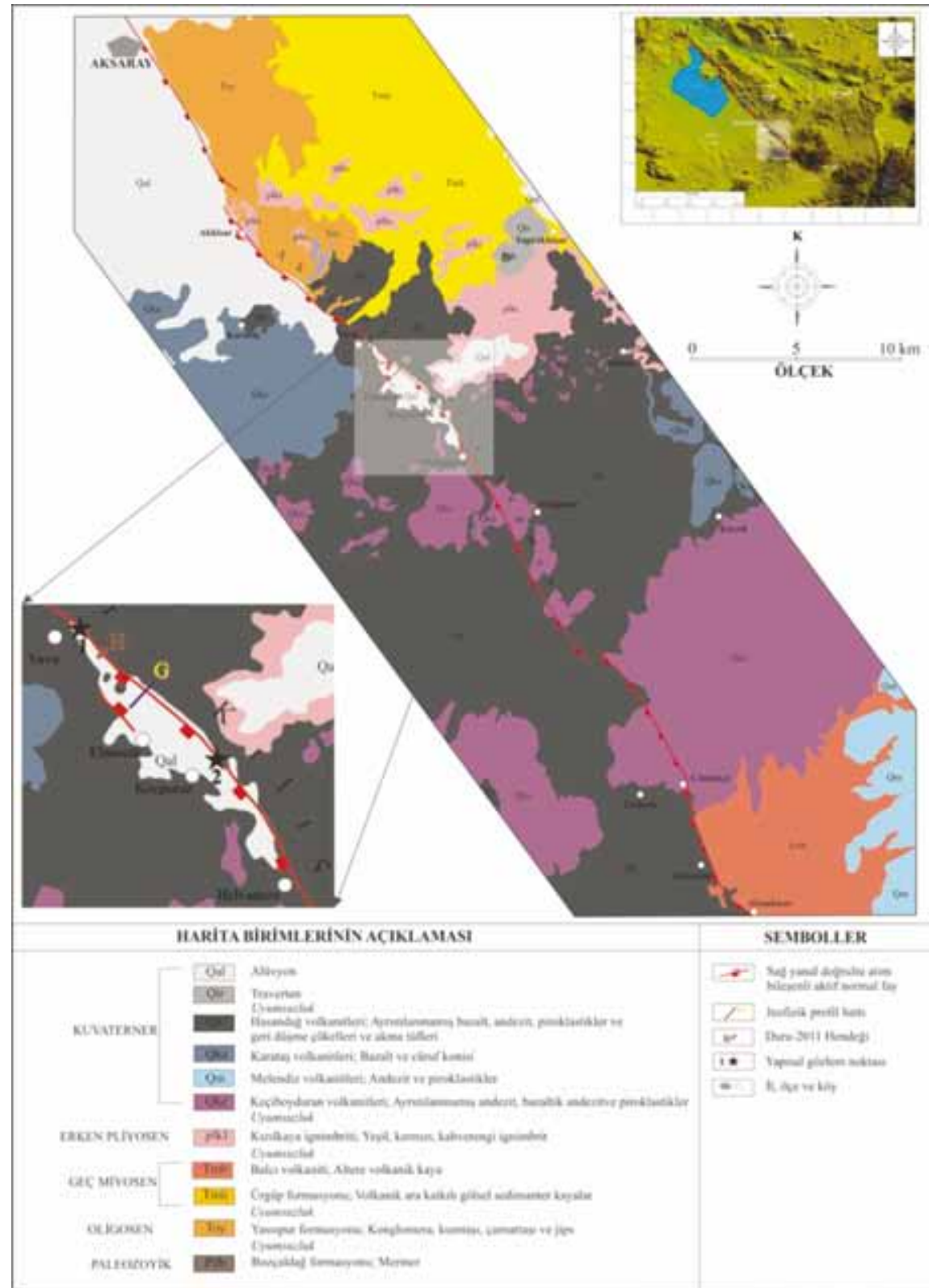

Şekil 3. Akhisar - Kılıç segmenti ve yakın civarının jeoloji haritası (Dönmez vd., 2005'ten düzenleyen Kürçer ve Gökten 2012).

Figure 3. Geological map of Akhisar-Kullç segment and its vicinity (modified from Dönmez et al., 2005; as cited in Kürçer and Gökten, 2012)

\section{Duru-2011 Hendeği}

Duru-2011 Hendeği, 2011 arazi çalışmaları sırasında bir trafik kazası sonucunda kaybettiğimiz MTA jeologlarından Dr. Mehmet Duru ve ekip arkadaşları jeoloji mühendisleri Taylan Hakan ve Selma Ceylan'a atfedilmiştir.

Duru-2011 Hendeği Akhisar-Kılıç segmentinin orta bölümünde yer alır (Bkz. Şekil 3). 
Hendek kazı alanındaki topografyanın kayıt altına alınabilmesi amaciyla, Total Station kullanılarak kazı alanı ve çevresinin 1/500 m ölçekli topografik haritası oluşturulmuştur. Daha sonra hendek ve hendekte saptanan aktif fay zonu, oluşturulan bu topografik harita üzerine taşınmıştır (Şekil 4).

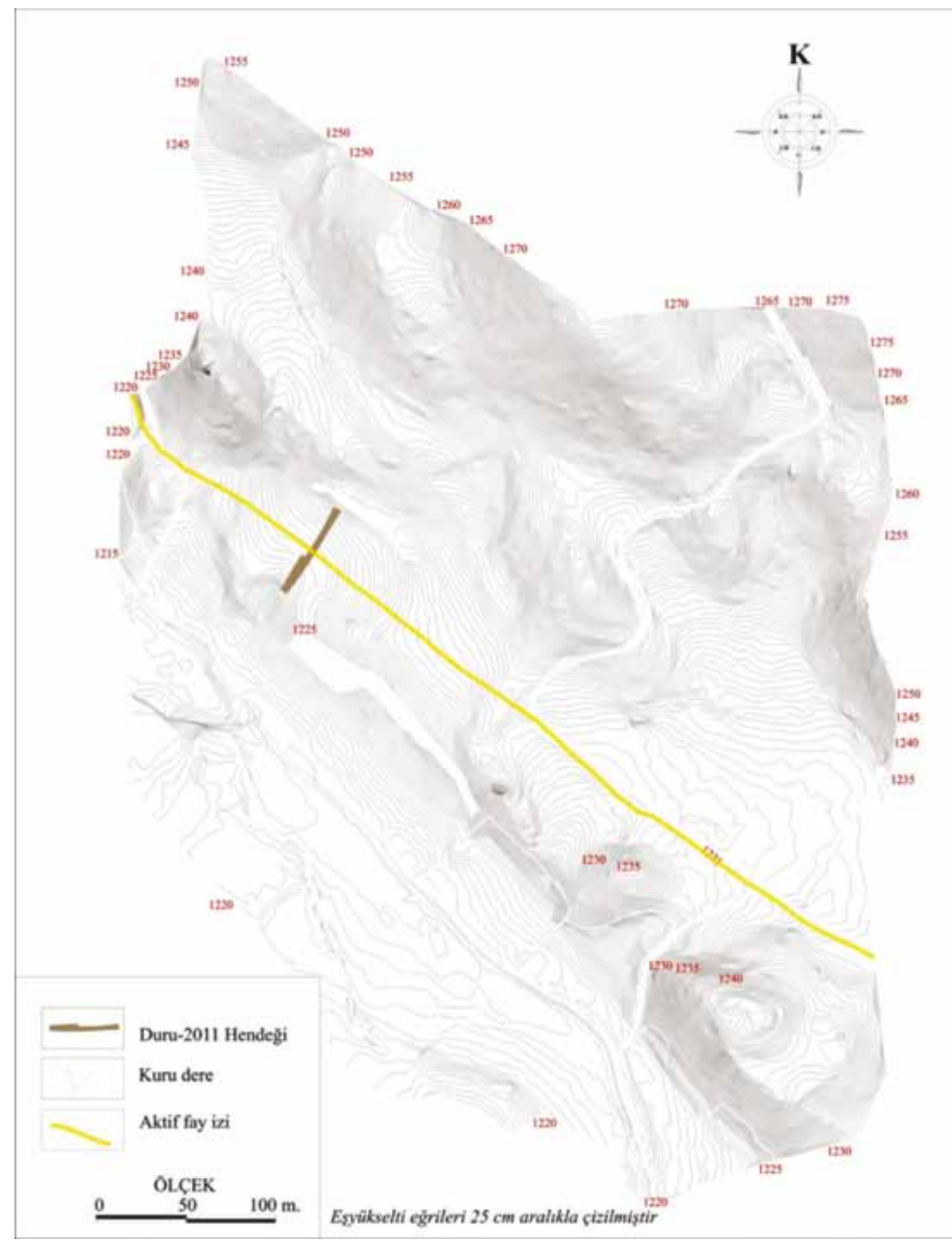

Şekil 4. Duru-2011 Hendek alanı ve çevresinin 1/500 m ölçekli mikrotopoğrafya haritası (Kürçer, 2012)

Figure 4. Topographic map of Duru-2011 Trench site and its vicinity (in scale of 1/500 m) (Kürçer, 2012). 
Hendek yer seçiminde, hendek alanının yakın kuzey ve güneyindeki fay düzlemi mostralarından faydalanılmıştır (Şekil 5). Buna ilaveten, hendek kazısı düşünülen alanın yakın güneyinde fay izine dik doğrultuda bir hat boyunca, $250 \mathrm{~m}$. aralıkla 8 adet Düşey Elektrik Sondaj (DES) yapılmıştır. DES'larda yaklaşık $2000 \mathrm{~m}$. derine kadar veri elde edilmiştir. Elde edilen DES verilerinden bir yer elektrik yapı kesiti türetilmiştir. Türetilen yer elektrik yapı kesitinde yüzeye kadar ulaşan bir fay tespit edilmiştir (Şekil 6). Yer Elektrik yapı kesitinde belirlenen fay verisi ve yapısal gözlemler jeomorfoloji ile bütünleştirilerek hendek yeri seçilmiştir.
Akhisar-Kılıç segmenti, Yuva ile Helvadere köyleri arasında uzanan çizgisel fay vadisinin doğu kenarını kontrol eder. Duru-2011 Hendeği, bu fay vadisinin içinde yer alan elipsoidal geometrili çöküntü alanında kazılmıştır (bkz. Şekil 3). Hendek alanı, Hasandağı Kuvaterner volkanizmasının ve fluviyal depolanma süreçlerinin etkisi altındadır. Hendeğin stratigrafik olarak tabanında yer alan, göreceli yaşlı kesimleri Hasandağ Kuvaterner Volkanizması'nın ürünü lav ve tüflerle temsil olunur. Bunların üzerinde yer alan daha güncel çökeller ise fluviyal süreçler ve bunlarla ara katk1lı volkan külleri ile temsil edilmektedir. 

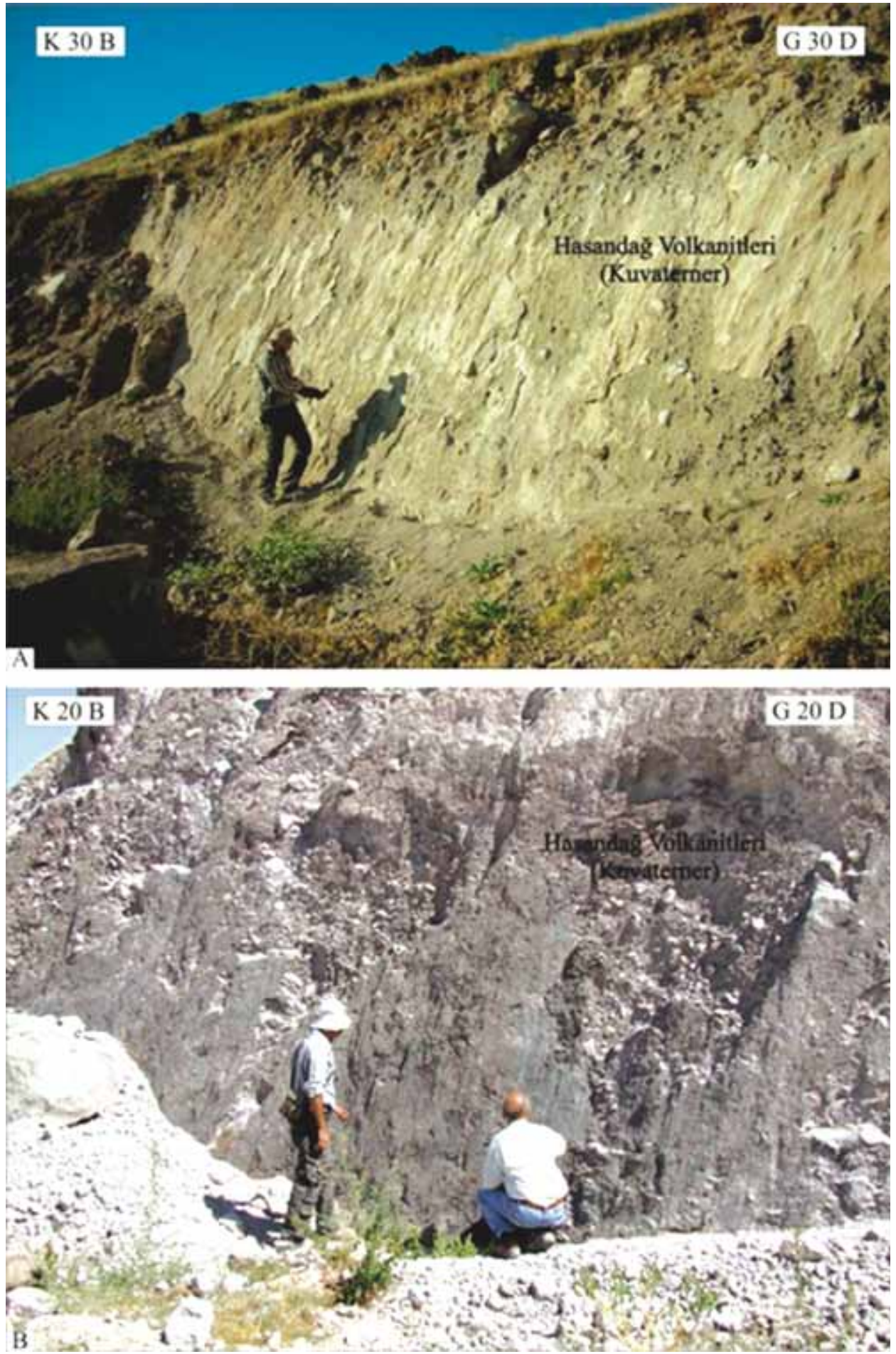

Şekil 5. Hasandağ volkanitlerini kesen Akhisar-Kılıç segmentine ait fay düzlemleri. A. Yuva Köyü GD’su, B. Koçpınar Köyü KD’su (Kürçer, 2012; Kürçer ve Gökten, 2012) (Lokasyonlar için Şekil 3’e bakınız).

Figure 5. Fault planes belonging to Akhisar-Kıllç segment that cuts Hasandă̆ volcanites. A. SE of Yuva village, B. NE of Koçpinar village (Kürçer, 2012, as cited in Kürçer and Gökten, 2012) (See figure 3 for locations) 


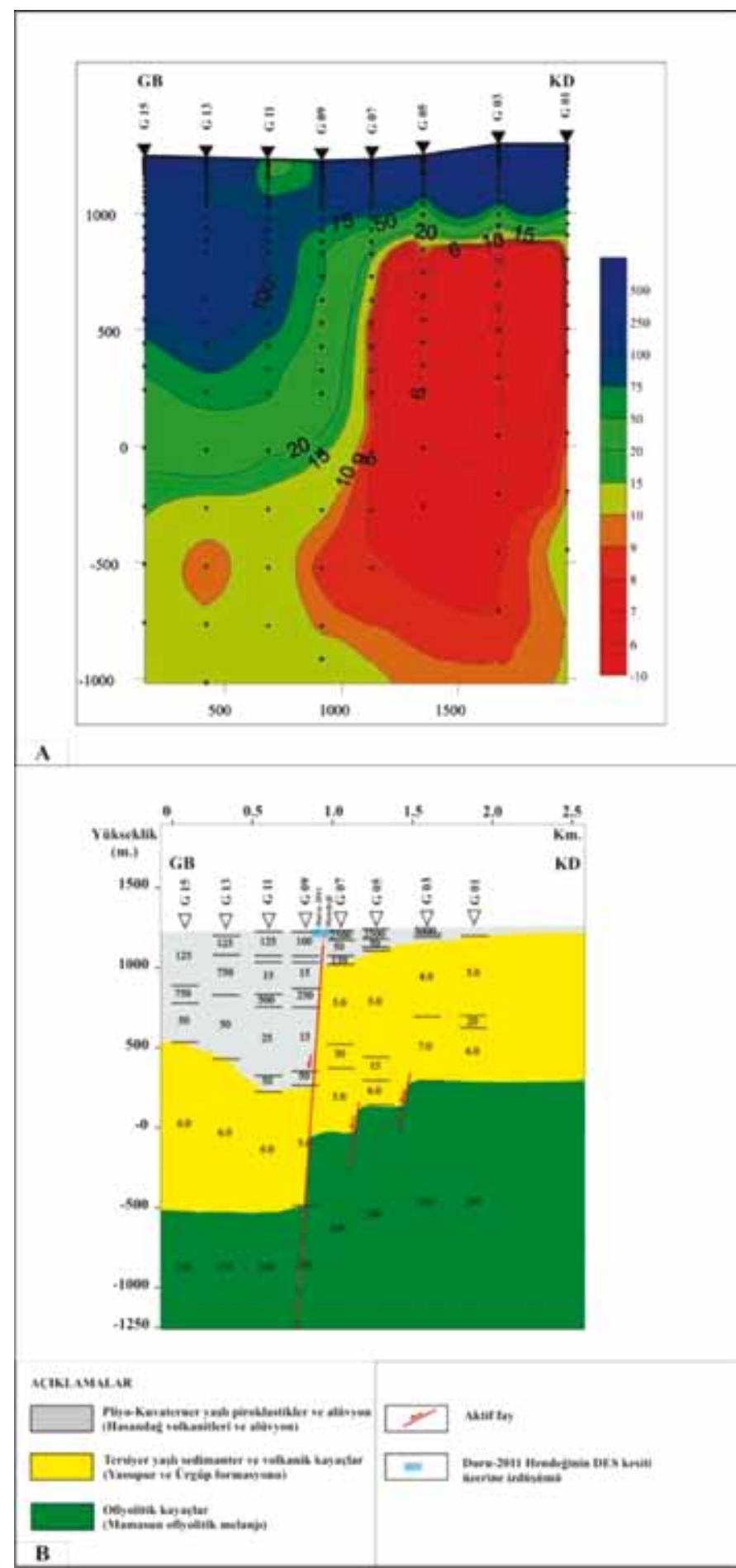

Şekil 6. Düş̧ey Elektrik Sondaj verilerinden üretilen A- Görünür eş özdirenç kesiti, B- Yer Elektrik Yapı Kesiti (Kürçer, 2012; Kürçer ve Gökten, 2012) (Profil lokasyonu için Şekil 3’e bakınız).

Figure 6. A. Apparent iso-resistivity cross-section, B. Geoelectric cross-section, generated from Vertical Electric Soundings (Kürçer, 2012, as cited in Kürçer and Gökten, 2012) (see figure 3 for profile location) 
Duru-2011 Hendeği, K $30^{\circ} \quad \mathrm{D}$ doğrultusunda, $55 \mathrm{~m}$ uzunluğunda, 6 metre genişliğinde, $9 \mathrm{~m}$ derinliğinde ve basamaklı olarak kazılmıştır (Şekil 7).

\begin{abstract}
Şekil 8'de Duru-2011 Hendek çalışmalarının bazı aşamaları sunulmuştur. Hendeğin tamamında $1 \mathrm{~m}^{2}$ karelajlama uygulanmış ve hendek el ile hendek loglama tekniği (manuel trench logging) ile loglanmıştır.
\end{abstract}

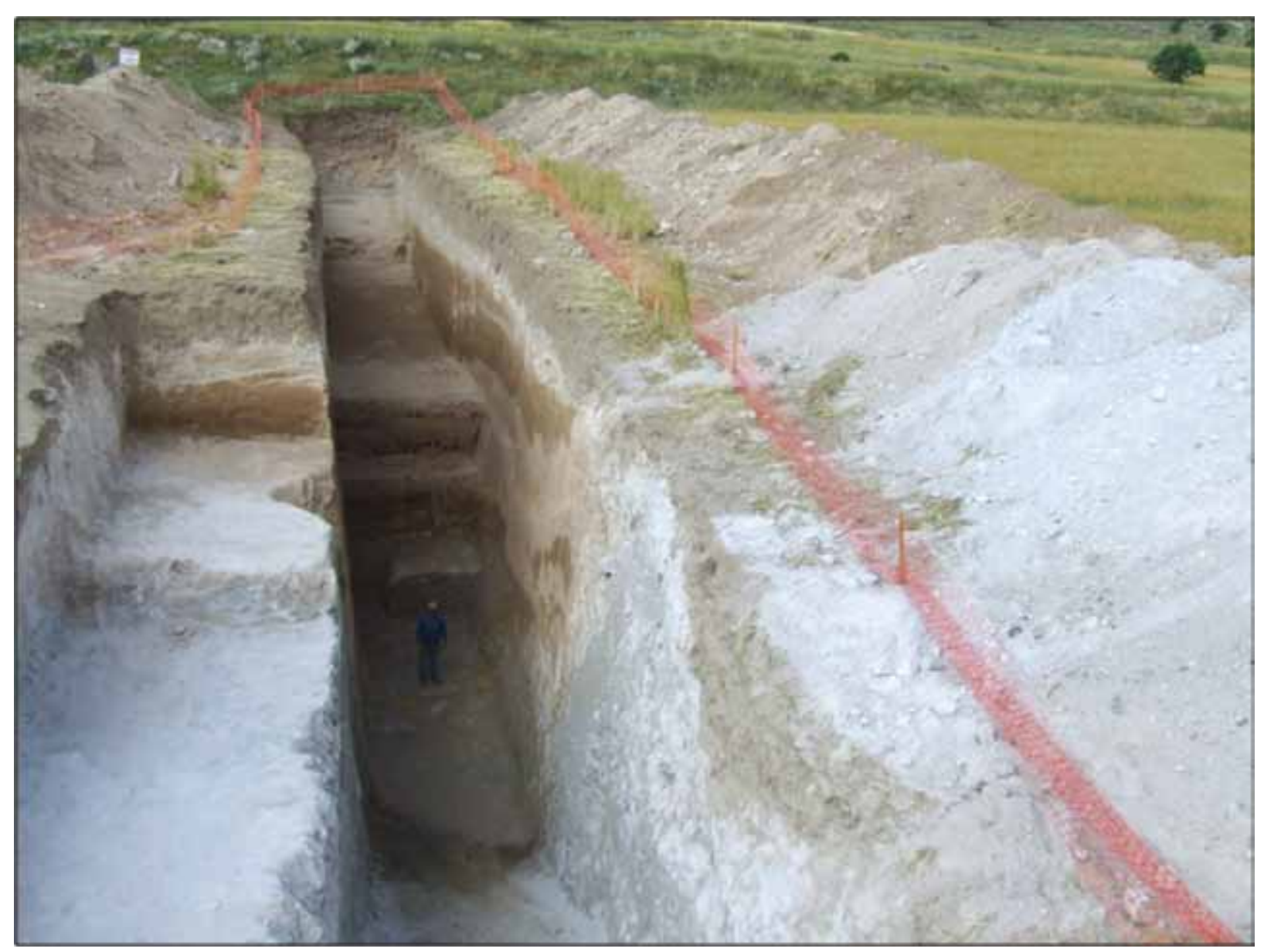

Şekil 7. Duru-2011 Hendeği genel görüntüsü (Bakış KD’ya) (Kürçer, 2012)

Figure 7. General view of Duru-2011 Trench (view from SW to NE) (Kürçer, 2012) 

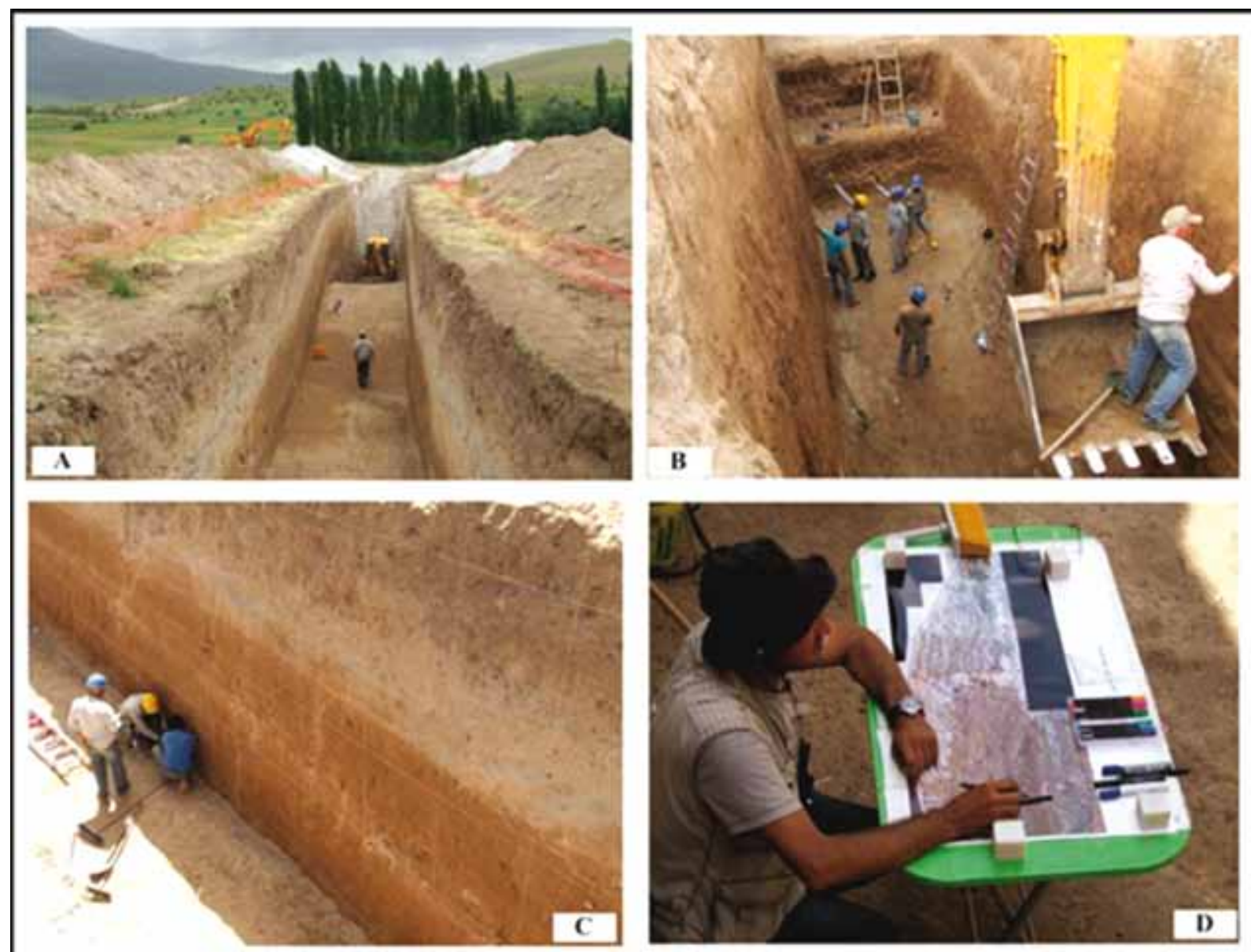

Şekil 8. Duru-2011 Hendek çalışmalarının bazı aşamaları. A-Kazı, B- Temizleme, C- Karelajlama, D-Loglama (Kürçer, 2012)

Figure 8. The stages of the trench work. A. Excavation, B. Cleaning, C. Gridding, D-Logging (Kürçer, 2012)

Şekil 9'da Duru-2011 Hendeği'ne ait GD duvar logu sunulmuştur. Duru-2011 Hendeği'nde toplam 16 stratigrafik seviye tanımlanmıştır. $\mathrm{Bu}$ birimlerin göreli olarak daha yaşlı olan ilk dördü Hasandağ volkanizmasıyla ilgili lav ve tüflerdir. Üstteki daha genç birimler ise sedimanter süreçlerde oluşmuş çökeller ve bunlarla yer yer ardalanmalı volkan külleridir. Duru-2011 Hendeği'nden toplam 9 adet toprak örneği derlenmiş ve BETA Analitik Laboratuvarı'nda (ABD) analiz $\left({ }^{14} \mathrm{C}-\mathrm{AMS}\right.$ ) ettirilmiştir (Çizelge 1). 


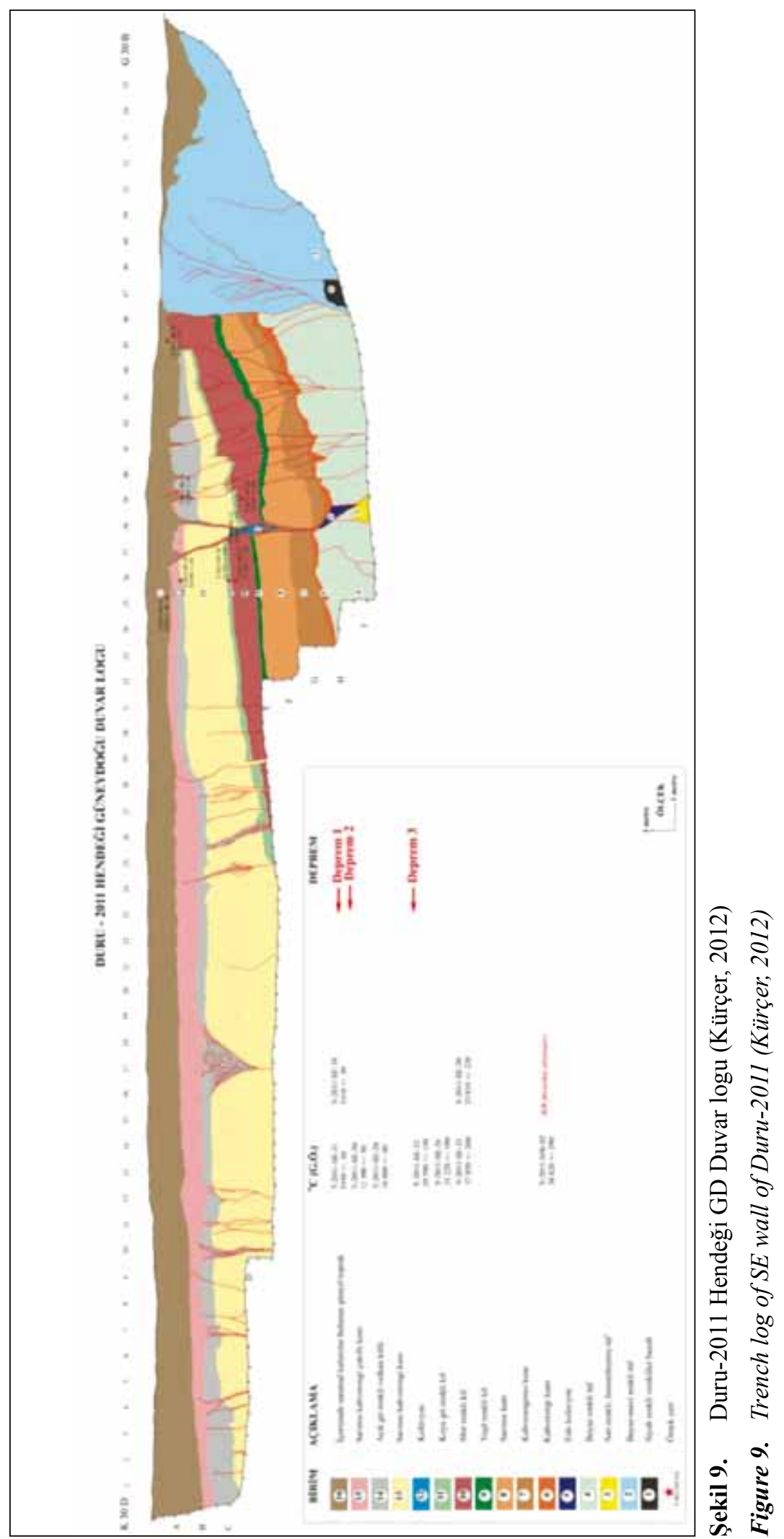


Çizelge 1. Duru-2011 Hendeği’nden derlenen numunelerin C-14 Yaş Tayini Sonuçları

Table 1. Results of ${ }^{14} \mathrm{C}$ Age Determination fort he samples collected from Duru-2011 Trench

\begin{tabular}{|l|l|l|l|l|l|}
\hline Beta No & Örnek No & Birim & Malzeme & Ölçülen yaş (G.Ö.) & $\begin{array}{l}\text { Kalibre edilmiş } \\
\text { Sigma 2 yaşları (G.ö.) }\end{array}$ \\
\hline 312717 & Y-2011-SE-18 & 16 & Organik sediment & $3310+/-30$ BP & $\begin{array}{l}\text { Cal MÖ 1720 to 1720 } \\
\text { (Cal GÖ 3680 to 3670), } \\
\text { Cal MÖ 1690 to 1530 } \\
\text { (Cal GÖ 3640 - 3480) }\end{array}$ \\
\hline 312723 & Y-2011-SE-31 & 16 & Organik sediment & $5550+/-30$ BP & $\begin{array}{l}\text { Cal MÖ 4460 - 4350 } \\
\text { (Cal GÖ 6410 - 6300) }\end{array}$ \\
\hline 312722 & Y-2011-SE-30 & 15 & Organik sediment & $12500+/-50$ BP & $\begin{array}{l}\text { Cal MÖ 13100 - 12620 } \\
\text { (Cal GÖ 15050 - 14570) }\end{array}$ \\
\hline 312721 & Y-2011-SE-28 & 14 & Organik sediment & $16660+/-60$ BP & $\begin{array}{l}\text { (Cal GÖ 20100 - 19800), } \\
\text { Cal MÖ 17760 - 17640 } \\
\text { (Cal GÖ 19700 - 19590) }\end{array}$ \\
\hline 312724 & Y-2011-SE-32 & 12 & Organik sediment & $29590+/-150$ BP & $\begin{array}{l}\text { Cal MÖ 32690 - 32140 } \\
\text { (Cal GÖ 34640 - 34080) }\end{array}$ \\
\hline 312720 & Y-2011-SE-26 & 11 & Organik sediment & $31220+/-180$ BP & $\begin{array}{l}\text { Cal MÖ 34410 - 33200 } \\
\text { (Cal GÖ 36360 - 35150) }\end{array}$ \\
\hline 312718 & Y-2011-SE-20 & 10 & Organik sediment & $33810+/-220$ BP & $\begin{array}{l}\text { Cal MÖ 37060 - 36540 } \\
\text { (Cal GÖ 39010 - 38490) }\end{array}$ \\
\hline 312719 & Y-2011-SE-25 & 10 & Organik sediment & $37850+/-260$ BP & $\begin{array}{l}\text { Cal MÖ 40820 - 40140 } \\
\text { (Cal GÖ 42770 - 42090) }\end{array}$ \\
\hline 312714 & Y-2011-NW-02 & 6 & Organik sediment & $38820+/-390$ BP & $\begin{array}{l}\text { Cal MÖ 41780 - 40610 } \\
\text { (Cal GÖ 43730 - 42560) }\end{array}$ \\
\hline
\end{tabular}

Hendek stratigrafisi, fay koluviyal kama geometrisi, fay kollarının yukarıya doğru sonlanması gibi paleosismolojik ölçütler ve ${ }^{14-} \mathrm{C}$ yaş verileri kullanılarak yapılan değerlendirmede, Duru-2011 Hendeği'nde son 23000 yıl içerisinde üç paleosismik olay (deprem) tanımlanmıştır.

$\mathrm{Bu}$ depremlerden ilki (Deprem 3), 12 numaralı koluviyal kamanın oluşumundan sorumlu depremdir. 11 numaralı koyu gri renkli kil çökeldikten sonra Deprem 3 meydana gelmiş ve bunun sonucunda 12 numaralı koluviyal kama gelişmiştir. 11 numaralı birimden elde edilen en genç yaş, G.Ö. $31220 \pm 180$ yıldır. 12 numaralı koluvyonu örten 13 numaralı birimden yaşlandırma için uygun malzeme bulunamadığı için örnek alınmamıştır. Bunun hemen üzerine gelen 14 numaralı açık gri renkli volkan külünden derlenen Y-2011-SE-28 numaral1 örnekten G.Ö. 16660 \pm 60 y1l yaş elde edilmiştir. Bunlara ilaveten 12 numaralı koluviyal kamanın kendisinden derlenen Y-2011-SE-32 numaralı örnekten G.Ö. $29590 \pm$ 150 yıl yaş elde edilmiştir. Koluviyal kamalar, paleosismoloji çalışmalarında depremlerin tarihlendirilmesinde doğrudan olay seviyesi olarak kullanılabilmektedir. Bu veriler ışığında, 
Duru-2011 Hendeği'nde tanımlanan ilk depremin (Deprem 3) yaşı G.Ö. $29590 \pm 150$ - G.Ö. 16660 \pm 60 arasında bulunmuştur. Bu depreme ilşkin 40 $\mathrm{cm}$ düşey yer değiştirme ölçülmüştür.

Duru-2011 Hendeği'nde tanımlanan ikinci deprem (Deprem 2) 15 numaralı sarıms1 kahverengi çakıllı kumu kesen ve içerisinde obsidiyen el aletleri parçaları gibi antropojenik kalıntılar bulunan 16 numaralı güncel toprak seviyesi tarafından örtülen faylanmayla ilşkilidir. $\mathrm{Bu}$ faylanmaya ait izler hendek kesitinin ilk 30 metresi içerisinde hemen her yerde görülür. $\mathrm{Bu}$ depremin tarihlendirilmesi amaciyla 15 numaralı birimden derlenen Y-2011-SE-30 numaralı örnekten G.Ö. $12500 \pm 50$ y1l yaş elde edilmiştir. 16 numaralı birimden ise Y-2011-SE-31 ve Y-2011-SE-18 numaralı örnekler derlenmiş ve bu örneklerden sırasıyla G.Ö. $5550 \pm 30$ ve G.Ö. 3310 \pm 30 yıl yaşlar elde edilmiştir. $\mathrm{Bu}$ yaş verilerine göre Deprem 2'nin yaşı G.Ö. $12500 \pm 50$ - G.Ö. $5550 \pm 30$ yılları arasında bulunmuştur.

Hendekte tanımlanan en güncel deprem (Deprem 1), 16 numaralı güncel toprak seviyesini kesen faylanmayla ilşkilidir. $\mathrm{Bu}$ depremin yaşlandırılması amacıyla 16 numaralı birimden derlenen Y-2011-SE-31 ve Y-2011-SE-18 numaralı örneklerden sirasıyla G.Ö. $5550 \pm 30$ ve G.Ö. $3310 \pm 30$ y1l yaşlar elde edilmiştir. En son depremin yaşı G.Ö. G.Ö. $3310 \pm 30$ ile günümüz aralığında bulunmuştur.

Diğer taraftan Kürçer ve Gökten (2012) tarafından Akhisar-Kılıç segmenti üzerinde yürütülen bir başka paleosismolojik hendek çalışmasında (Bağlarkayası-2010 Hendeği) son 10500 yıl içerisinde iki deprem tanımlanmış ve tarihlendirilmiştir. Aynı segment üzerindeki iki hendekten elde edilen deprem verileri fay penceresi yöntemiyle (McCalpin, 1987) değerlendirilmiş ve değerlendirme sonucu Şekil 10'da sunulmuştur. Buna göre Akhisar-Kılıç Segmenti üzerinde son 23 000 y1l içerisinde 3 deprem meydana gelmiştir. $\mathrm{Bu}$ depremlerden ilki (Deprem 3) G.Ö. $29590 \pm 150$ - G.Ö. $16660 \pm 60$ yılları arasında (yaklaşık G.Ö. 23125 y1l1) meydana gelmiştir. Bu depremden yaklaşık 13095 yıl sonra G.Ö. $10410 \pm 50$ G.Ö. $9650 \pm 50$ yılları arasında (yaklaşık G.Ö. 10 030 y1l1) bir deprem (Deprem 2) daha meydana gelmiştir. Akhisar-Kılıç Segmenti üzerinde tarihlendirilen en güncel deprem (Deprem 1), bir önceki depremden yaklaşı 7690 yıl sonra G.Ö. $3310 \pm 30$ - G.Ö. $1370 \pm 40$ yılları arasında (yaklaşık G.Ö. 2340 yılı) meydana gelmiştir. $\mathrm{Bu}$ yaş verilerine göre Akhisar-Kılıç Segmenti üzerindeki ortalama deprem tekrarlanma aralığı 10390 yıl olarak önerilmektedir.

Hendeklerde saptanan depremlerde ortalama $35 \mathrm{~cm}$ yer değiştirme miktarları ölçülmüştür. Ortalama deprem tekrarlanma aralığ1 (10390 y1l) ve her bir depremde meydana gelen ortalama düşey yer değiştirme miktarı $(35 \mathrm{~cm})$ dikkate alınarak yapılan hesaplamada AkhisarKılıç Segmenti üzerindeki yakın dönem (geç Pleyistosen-Holosen) düşey kayma hızı 0,034 mm/yıl olarak hesaplanmıştır. Bu değer Tuz Gölü Fay Zonu üzerinde Cihanbeyli Formasyonu ve Kızılkaya ignimbiritlerindeki toplam normal eğim atım miktarları ve yaş verileri kullanılarak hesaplanan Pliyosen'den günümüze uzun dönem düşey kayma hızı (0,046 mm/yıl) (Kürçer, 2012) ile yaklaşık uyumludur. 


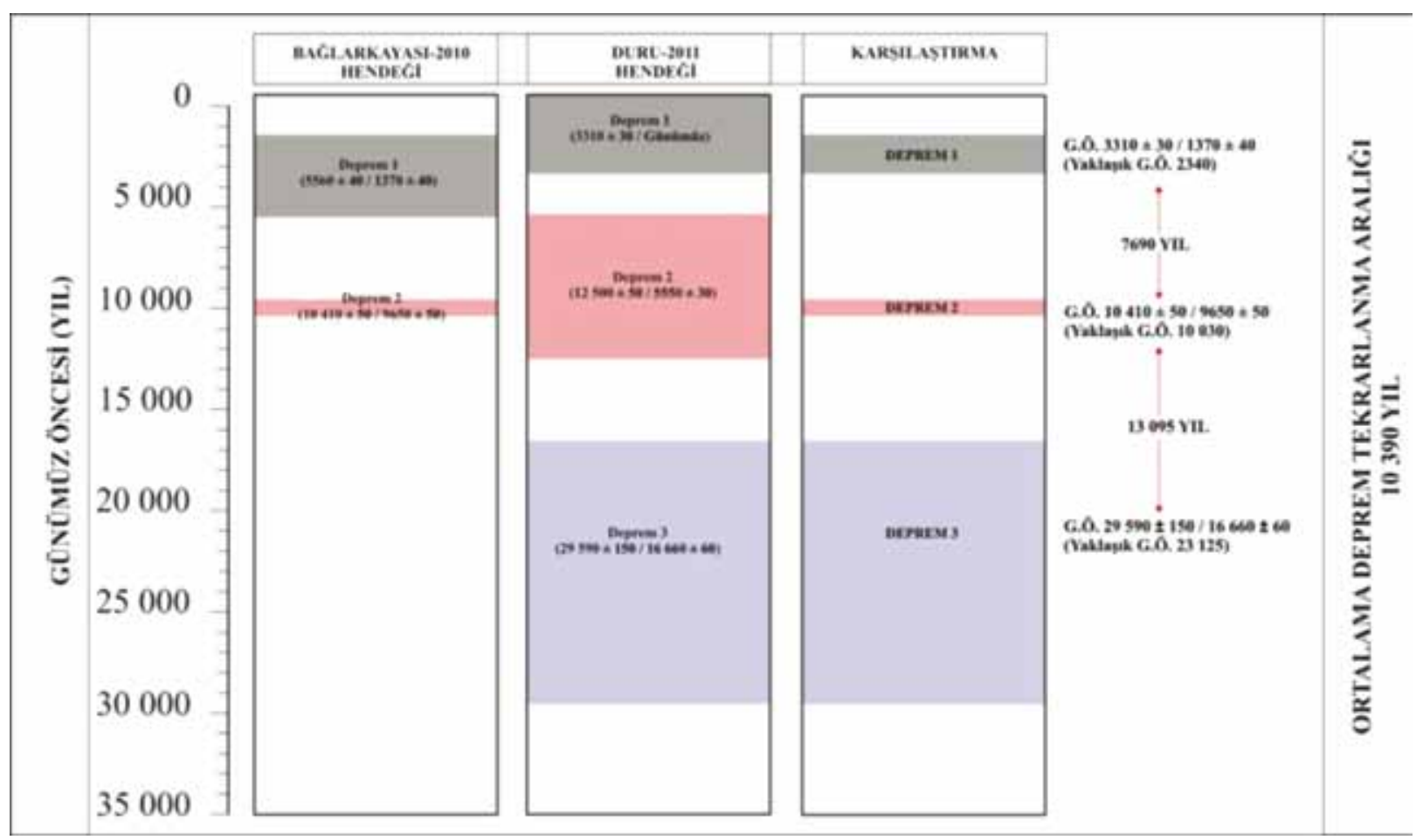

Şekil 10. Bağlarkayası-2010 ve Duru-2011 Hendekleri’nde tanımlanan depremlerin “fay pencesi” yöntemi (McCalpin, 1987) kullanılarak değerlendirmesi (Kürçer, 2012)

Figure 10. Evaluation of earthquakes which were determined in Bağlarkayast-2010 and Duru-2011 Trenches using "fault window method"(Kürçer, 2012)

Tuz Gölü Fay Zonu'nun 27 km uzunluğundaki Akhisar-Kılıç segmentinin, tamamının kırıldığı varsayılarak, üretebileceği maksimum deprem büyüklüğü Wells ve Coppersmith (1994) tarafindan normal faylar için önerilen görgül eşitlikler kullanılarak hesaplanmıştır. Hesaplamalardan elde edilen maksimum deprem büyüklüğü yalnızca Akhisar-Kılıç segmentinin tamamının kırılacağı varsayılarak hesaplanmış değerdir. AkhisarKılıç segmentinin, komşu diğer segment ya da segmentlerle birlikte kırılması durumunda daha büyük depremler üretebileceği gözden uzak tutulmamalıdır.

Buna göre Akhisar-Kılıç Segmenti'nin üretebileceği maksimum deprem büyüklüğü
(M), maksimum yer değiştirme miktarı (MD) ve ortalama yer değiştirme miktarı (AD) aşağıdaki gibi hesaplanmıştır;

$$
\begin{aligned}
& \mathbf{M}=\mathbf{a}+\mathbf{b} \times \log (\mathbf{S R L}) \\
& a=4.86 \\
& b=1.32 \\
& S R L=27 \mathrm{~km} \\
& M=4.86+1.32 \times \log (27) \\
& M=6.74 \text { olarak hesaplanmıştır. } \\
& \log (\mathbf{M D})=\mathbf{a}+\mathbf{b} \times \mathbf{M} \\
& M=6.74 \\
& a=-5.90 \\
& b=0.89
\end{aligned}
$$


$\log (\mathrm{MD})=0,0986$

$\mathrm{MD}=1.25$ metre olarak hesaplanmıştır.

$\log (\mathrm{AD})=\mathbf{a}+\mathbf{b} \times \mathbf{M}$

$\mathrm{M}=6.74$

$\mathrm{a}=-4.45$

$b=0.63$

$\log (\mathrm{AD})=-0.2038$

$\mathrm{MD}=0.62$ metre olarak hesaplanmıştır.

Duru-2011 Hendeği'nde bir deprem için ölçülen yer değiştirme miktarı yaklaşık $35 \mathrm{~cm}$ dir. Bu değer Wells ve Coppersmith (1994) tarafindan normal faylar için önerilen görgül eşitliklerden hesaplanan ortalama yer değiştirme miktarından küçüktür. Bu durum, Akhisar-Kılıç segmentinin bir miktar sağ yanal doğrultu atım bileşenine sahip olması ile açıklanabilir.

\section{PALEOSISMOLOJIKK ÜÇ BOYUTLU SANAL FOTOĞRAFLAMA YÖNTEMİ - DURU-2011 HENDEK UYGULAMASI}

Paleosismolojik araştırmalarda hendek açma yöntemi, kayda değer veriler sağlayan en önemli yöntemlerden biridir. Faylanma tipine bağlı olarak aktif fay izine dik ya da koşut olarak kazılan hendekler içerisinde sedimantoloji, stratigrafi ve yapısal jeoloji esaslarına göre jeolojik değerlendirmeler yapılır. Daha sonra, eski depremlerin tarihlendirilmesine olanak sağlayacak çökellerden numuneler derlenir ve uygun radyometrik yaşlandırma teknikleri kullanılarak tarihlendirilir. Paleosismolojik hendeklerin kazı tipleri ve boyutları, çalışılan fayın özelliğine (faylanma tipi, yıllık kayma hızı, deprem tekrarlanma aralığı, her depremde meydana gelen yer değiştirme miktarı, bilinen son tarihsel depremden günümüze kadar geçen süre vb.) ve hendek sahasının fiziksel değişkenlerine (yer altı su durumu, hendek çökellerinin stabilitesi vb.) göre değişebilir. Göreceli olarak daha düşük kayma hızına sahip (< $1 \mathrm{~mm} / \mathrm{y} 1)$ ve eğim atımın baskın olduğu faylarda yapılan paleosismolojik kazılar, daha derin ve kapsamlı yapılmaktadır. Yer altı su seviyesinin sı ğ olduğu ya da hendek duvarlarının duraylı olmadığı durumlarda, hendekler güvenlik açısından basamaklı yahut şevli kazılmaktadır. Hendek duvarlarının temizlenmesinin ardından, hendekteki jeolojik detay özellikler dikkate alınarak karelajlama (gridding) yapilır. Karelajlamada genellikle $1 \mathrm{~m}$ grid aralığ 1 standart kabul edilmektedir. Karelajlamanın ardından, hendeğin görsel olarak kayıt altına alınması gerekir. Bu aşamada karşılıklı hendek duvarlarının belirli bir ölçekte loglanması ve fotoğraflanması gerekir. Loglama iki şekilde yapılabilir. El ile loglama tekniğinde, hendek duvarlarındaki her bir karelaj genellikle 1/20 m. ölçeğinde küçültülerek çizilir ve ardından bu çizimler birleştirilerek hendek duvarının tamamina ait duvar logu elde edilir. Fotomozayik loglamasında ise hendek duvarının yeter sayıda fotoğrafı çekilir ve bilgisayar ortamında çeşitli yazılım programları kullanılarak bu fotoğraflar birleștirilir. Hendek duvarının tamamına ait bir fotomozayik oluşturulur ve loglama bu fotoğraf üzerinden yapılır. Fotomozayik loglama tekniği, çizimden kaynaklanabilecek hata oranını en aza indirme olanağ1 sağladığı ve hızlı bir yöntem olduğu için son y1llarda paleosismolojide sıkça kullanılmaktadır. Ancak bu yöntem, fotoğrafların birleştirilmesinde hatalara neden olduğu ve fotoğrafta bozulmalar meydana geldiği için derin ve basamaklı kazılarda yetersiz kalmaktadır.

Paleosismolojik Üç Boyutlu Sanal Fotoğraflama Yöntemi ilk defa Kürçer (2012) tarafından Tuz Gölü Fay Zonu üzerinde yürütülen paleosismoloji çalışmalarında uygulanmıştır. Daha sonra yöntemin esasları ve ilk uygulaması Kürçer ve Gökten (2012) tarafından yayınlanmıştır. Bu 
çalışma, yöntemin uygulama esaslarını içeren ikinci çalışma niteliğindedir.

Panoramik görüntüleme sağlayan kameralara ilişkin uygulamalarda, özellikle görüntü işleme programlarının gelişmesine bağlı olarak son yıllarda önemli gelişmeler yaşanmıştır. $\mathrm{Bu}$ tür kameralar güvenlik, tele-konferans, tanıtım, sanal gezi, robot navigasyonu gibi çeşitli alanlarda yaygın olarak kullanılmaya başlanmıştır (Baştanlar ve Yardımc1, 2005; Ergün ve Şahin, 2009). Kameranın görüş açısının her zaman insanın görüş açısından küçük olması ve geniş objelerin görüntüsünün tek bir fotoğraf içinde görüntülenememesi nedeniyle, fotoğrafçılığın başından beri panorama yaratılması talebi uyanmıştır (Parian, 2007). Fotoğrafik anlamda panorama elde etme çabaları 1800'lü yılların sonlarında, farklı doğrultulardan çekilmiş birkaç fotoğrafın tam panorama elde etmek amaciyla birleştirilmesi ile gerçekleştirilmiştir (Baştanlar, 2005). "Panorama" Yunanca iki kelimenin birleştirilmesi ile oluşan bir kelimedir. "Pan" bütün, "horama" görüş anlamındadır (Baştanlar, 2005). Geleneksel fotoğraf ile panoramik fotoğraf arasındaki fark, bir şehre bir küçük ofis camından bakmak ile çatının üstünden bakmak arasındaki farka benzer (Kwiatek, 2005). Fotogrametrinin temel amaçlarından birisi, gerçek görüntüyü sanal ortama taşımak suretiyle, izleyicilerin ve okuyucular üzerinde "gerçekten oradaymış duygusu" uyandırmaktır. Son yıllarda İnternet ve multimedya teknolojilerinin gelişmesi ile fotogrametride önemli gelişmeler kaydedilmiş ve Üç Boyutlu Sanal Fotoğraflama Tekniği çeşitli alanlarda uygulanmaya başlanmıştır. Yöntem, mimarlık, turizm, müze tanıtımı gibi farklı sektörlerde sıkça kullanılıyor olmasına karşın, yerbilimlerinde ve paleosismolojide bir uygulaması bulunmamaktadır.
Yerbilimlerinin uygulama alanı doğadır. Doğada yapılan çalışmaların veri kaybı olmadan ve yüksek çözünürlükte okuyucuya sunulması önemlidir. Paleosismolojik hendek çalışmaları, kapsamlı, detaylı ve yüksek bütçeli çalışmalardır. Hendek çalışmalarının belirli bir zaman dilimi içerisinde ve belirli standartlarda tamamlanması gerekir. Hendek alanının kendine özel fiziksel koşulları (Yer altı su durumu, hendek çökellerinin stabil olmaması vb.) bazen çalışmaları güçleştirmekte, yıkılma ve göçmeler nedeniyle can ve mal kaybina neden olmaktadır. $\mathrm{Bu}$ olumsuzlukların giderilebilmesi için hendeklerin mümkün olduğunca kapsamlı kazılması ve olabildiğince çalışmanın hızlı ve kaliteli biçimde tamamlanması gerekir.

Paleosismolojik Üç Boyutlu Sanal Fotoğraflama Yöntemi, hendek içerisindeki tüm detayın okuyucuya veri kaybı olmadan, yüksek çözünürlükte aktarılmasına olanak sağlar. Ayrıca, okuyucu doğrudan hendek duvar görüntüsünü görebildiği için, bu yöntemle okuyucuya yorum hakkı tanınmış olmaktadır. Yöntem, hendek loglamasına da olanak sağlamaktadır. Bunun için herhangi bir mercek kalibrasyonuna gerek duyulmamaktadır. Ancak, yöntemde kullanılan fotoğraflar ortorektifikasyon işlemini içermemektedir.

Paleosismolojik Üç Boyutlu Sanal Fotoğraflama Yöntemi başlıca dört aşamadan oluşur. Bunlar;

1- Planlama,

2- Fotoğraflama,

3- Fotoğrafların birbirine eklenmesi (Stitching) ve sahnelerin oluşturulması,

4- Sahnelerin birleştirmesi ve sanal tur oluşturulmasıdır. 


\section{Planlama}

Bir hendek çalışmasının üç boyutlu olarak fotoğraflanabilmesi için öncelikle fotoğraflama yapılacak noktaların sayılarının ve yerlerinin planlanması gerekir. Nokta sayısı planlanırken; hendekteki paleosismolojik ayrıntı, hendeğin boyutu ve kazı biçimi dikkate alınmalıdır. Fotoğraflama yapılacak noktaların yerleri belirlenirken, hendek alanında hiçbir kör noktanın kalmamasına özen gösterilmelidir. Ancak bu koşulda hendeğin tamamına ait bir sanal tur elde etmek mümkün olabilmektedir. Duru-2011 Hendek çalışmasında 22 noktada fotoğraflama yapılmıştır. Fotoğraf çekilen noktaların, hendek duvarlarında fay içeren bölümlere yakın olmasına özen gösterilmiştir. Hendeğin bir duvarındaki fayın karşı duvardaki devamının takibi açısından, hendek tabanının da titizlikle temizlenmesi ve fay izlerinin tabanda da belirginleştirilmesi gerekmektedir.

Paleosismolojik üç boyutlu sanal fotoğraflamaya başlamadan önce, hendeğin tamamını kapsayan ve fotoğraflama yapılacak noktaları gösteren genel bir fotoğraf çekilmelidir. $\mathrm{Bu}$ fotoğraf mümkün ise havadan dik açıyla veya yüksekten eğik açıyla çekilebilir. Genel hendek fotoğrafi, son aşamada sanal tur gezintisinin oluşturulmasında yer bulduru fotoğrafı olarak kullanılacaktır. Örneğin Duru-2011 Hendeği’ne ait genel hendek fotoğrafi, hendek güneybatı girişinden eğik açı ile çekilmiştir (Şekil 11).

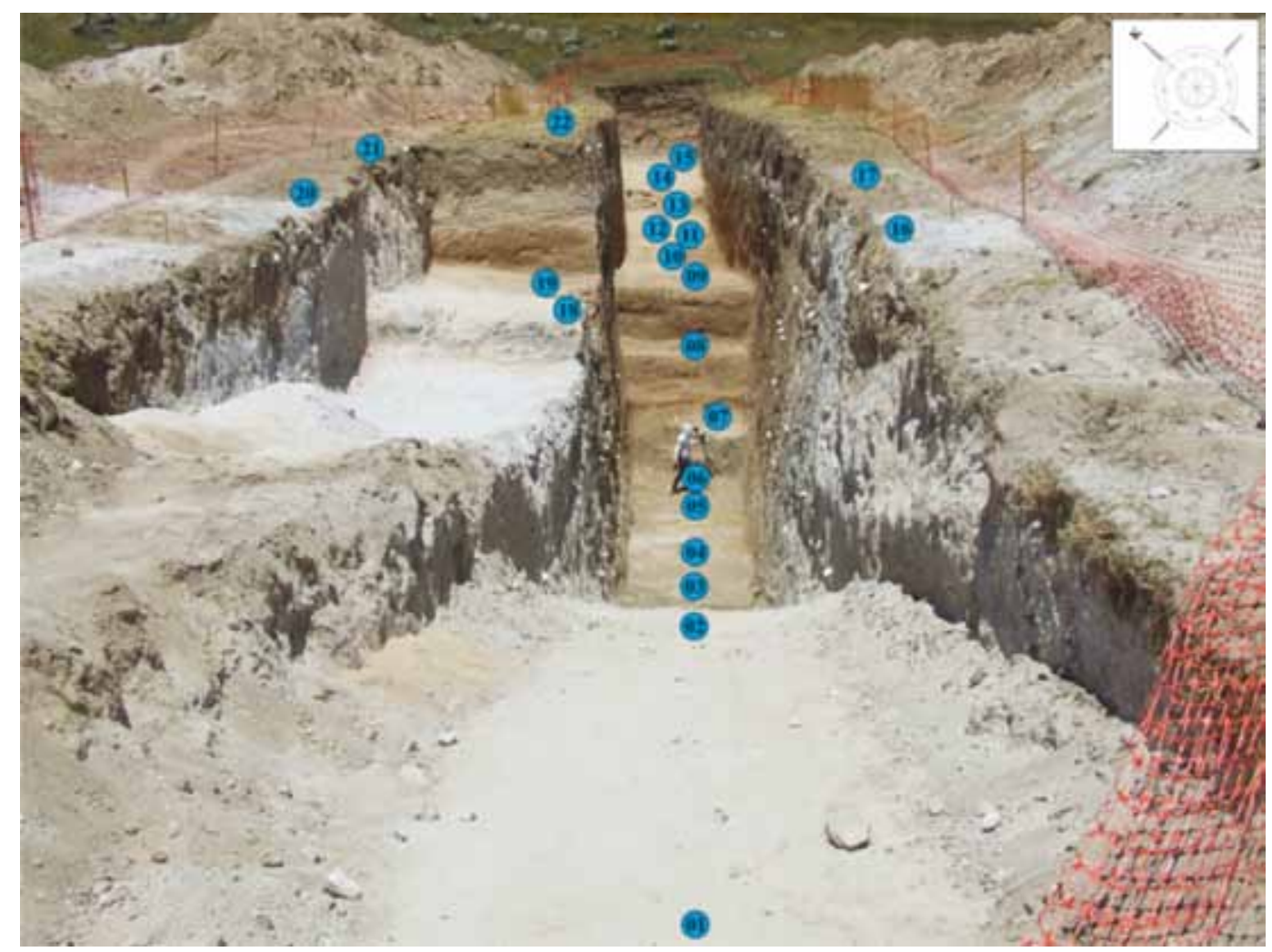

Şekil 11. Duru-2011 Hendeği'nin genel görüntüsü. Mavi içi dolu daireler, hendekte fotoğraflama yapılan noktaları temsil etmektedir (GB'dan KD’ya bakış).

Figure 11. General view of Duru-2011 Trench. Blue filled circles represent the points where photographs were taken from trench (View fron $S W$ to $N E$ ) 
$\mathrm{Bu}$ yöntem sonucunda elde edilecek sanal turda, görüntünün mümkün olduğunca berrak olması gerekir. Bunun için, fotoğraflama yapılmadan bir gün önce, hendek duvarlarına güneş 1şığının hangi saatte hangi açıyla geldiğinin kontrol edilerek kayıt altına alınması gerekir. Böylece, hangi noktada hangi saatte fotoğraf çekileceği planlanabilir. Her noktada 8 fotoğraf çekileceğinden, fotoğraflama süresi açısından bir nokta için ortalama 15 dakika öngörülebilir.

\section{Fotoğraflama}

Paleosismolojik Üç Boyutlu Sanal Fotoğraflama Yöntemi için gerekli yazılım ve donanımlar Çizelge 2'de sunulmuştur. $60^{\circ}$ açıyla çekilir ve böylece o noktanın $360^{\circ}$ yatay görüntüsü elde edilmiş olur. Daha sonra söz konusu noktanın gökyüzü ve zemin görüntüsü de iki ayrı fotoğraf halinde çekilir ve böylece o noktanın düşey düzlemdeki görüntüsü elde edilmiş olur. Böylelikle bir noktaya ait, yatay düzlemde 6 , düşey düzlemde iki olmak üzere toplam 8 fotoğraf çekilmiş olur.

\section{Fotoğrafların birbirine eklenmesi (Stitching) ve sahnelerin oluşturulması}

Paleosismolojik Üç Boyutlu Sanal Fotoğraflama Yöntemi çoğunlukla bazı bilgisayar programları kullanılarak uygulanan, zaman zaman da manuel olarak müdahale gerektiren bir yöntemdir.

Çizelge 2. Paleosismolojik Üç Boyutlu Sanal Fotoğraflama Yöntemi için gerekli yazılım ve donanımlar (Kürçer, 2012; Kürçer ve Gökten, 2012)

Table 2. The hardware and software required for Paleoseismological Three Dimensional Virtual Photography Method (Kürçer, 2012, as cited Kürçer and Gökten, 2012)

\begin{tabular}{|l|l|l|l|}
\hline Yazılım & Kullanım amacı & Donanım & Kullanım amacı \\
\hline Adope Photoshop CS5 & Renk ve 1̧̧ık düzeltmesi & Üç ayak & Fotoğraflama \\
\hline PTGui Pro 9.0 & $\begin{array}{l}\text { Fotoğrafların birbirine } \\
\text { dikilmesi }\end{array}$ & Dijital kamera & Fotoğraflama \\
\hline Cubic Converter 2.2.1 & $\begin{array}{l}\text { Fotoğrafların birbirine } \\
\text { dikilmesi ve sahnelerin } \\
\text { oluşturulması }\end{array}$ & Panoramik Kafa & Fotoğraflama \\
\hline PTLens 1.5.3 & Distorsiyon düzeltmesi & Balıkgözü mercek & Fotoğraflama \\
\hline Panotour Pro 1.6.0 & Sanal tur oluşturma & Bilgisayar & Büro çalışması \\
\hline Web Tarayıcı & $\begin{array}{l}\text { Internet Explorer, Google } \\
\text { Chrome, Mozilla Firefox }\end{array}$ & & \\
\hline
\end{tabular}

$\mathrm{Bu}$ çalışmada, Manfrotto 055xprob tripod, Nikon D200 Model ve 10.2 mega piksel özellikli Dijital fotoğraf makinesi, Manfrotto sph303 panoramik kafa ve $180^{\circ}$ görüş açısına sahip Nikkor balıkgözü objektif kullanılmıştır.

Fotoğraflama aşamasında, her noktada 8 fotoğraf çekilir. Bunlardan altısı yatay düzlemde
Fotoğraftan üretilecek olan sanal turun mümkün olduğunca gerçekçi olabilmesi için, ham fotoğraflarda bazı düzeltmelere ihtiyaç duyulmaktadır.

Bu aşamada öncelikle, her noktada çekilen 8 fotoğrafin Adope Photoshop CS5 programında renk ve 1 şı düzeltmeleri yapılır. Ardından, 
PTGui Pro 9.0 programı kullanılarak fotoğraflar birbirine dikilmek suretiyle birleştirilir (stitching). Birleştirmenin ilk aşamasında yatay düzlemde çekilen 6 fotoğraf ve düşey düzlemde çekilen gökyüzü görüntüsü kullanılmaktadır. Birleştirme işlemi yapılırken fotoğrafların ortak alanlarının çakıştırılması aşamasında zaman zaman manuel düzeltmeler gerekebilir. Birleştirme işleminin ilk aşaması tamamlandığında zemin görüntüsü hariç tüm noktalar birbirine dikilmiş olur.

Dikilen 7 fotoğraf daha sonra Cubic converter 2.2.1 programina aktarılır. Cubic converter 2.2.1 programı, dikilen 7 fotoğraftan oluşan görüntüyü küp şeklinde 6 parçaya ayırmak suretiyle parça fotoğraflar meydana getirir. Bu parça fotoğraflardan bir tanesi, henüz tamamlanmamış olan zemin fotoğrafıdır.
Zemin fotoğrafının tamamlaması için, ilk başta çekilen ham fotoğraflardan zemine ait olan fotoğraf, PTlens 1.5.3 programında açılır. Bu programda distorsiyon düzeltmesi yapıldıktan sonra elde edilen görüntü, zemine ait parça fotoğraf ile montajlanır. Montajlanan fotoğraf yeniden Cubic converter 2.2.1 programına aktarılır ve böylece zemin fotoğrafı tamamlanmış olur. Son olarak, tüm sahneye ait görüntü Cubic converter 2.2.1 programindan TIFF formatında kaydedilir. Şekil 12'de Duru-2011 Hendeği'ne ait 15 numaralı noktaya (Bkz. Şekil 11) ait dikilmiş ve birleştirilmiş sahne görüntüsü örnek olarak sunulmuştur.

Tüm sahneler için bu işlemler yapılarak TIFF formatında toplam 22 dosya elde edilmiştir.

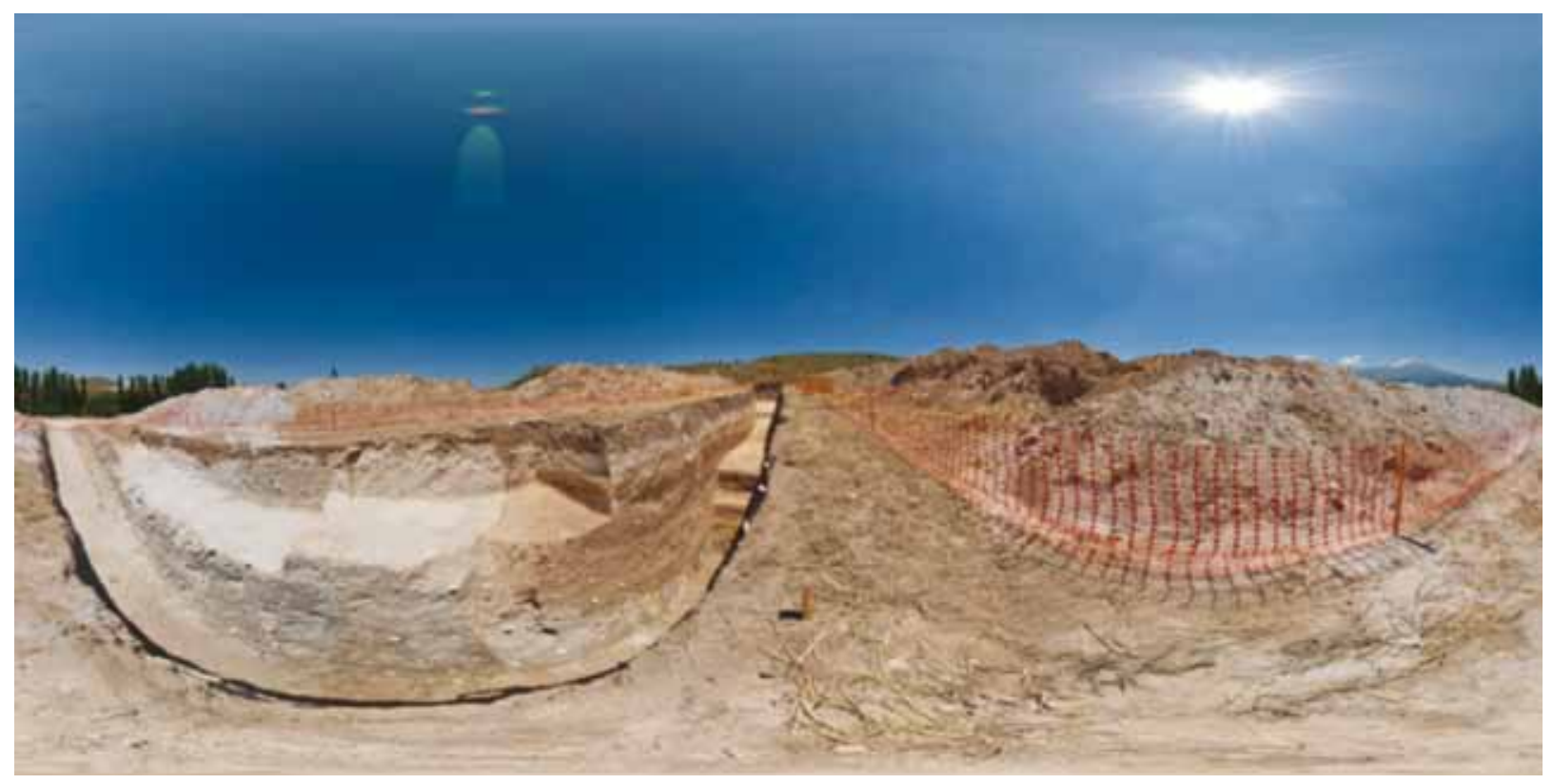

Şekil 12. Duru-2011 Hendeği'ndeki 15 numaralı(Bkz. Şekil 11) noktaya ait fotoğrafların dikilmesi ve birleştirilmesi sonucunda elde edilmiş sahne görüntüsü.

Figure 12. The scene image obtained as a results of stitching and connecting the photographs belonging to the point 15 (see figure 11) of Duru-2011 Trench. 
Sahnelerin birleştirilmesi ve sanal tur oluşturulması

Birleştirilen ve TIFF formatında kaydedilen tüm sahneler Panotour Pro 1.6.0 programında açılır. Sahnelerin birbirleriyle olan geçişlerinin yapılabilmesi için geçiş linkleri oluşturulur. Daha sonra yerbulduru fotoğrafi programa import edilir ve geçiş linkleri yerbulduru fotoğrafına da eklenir. Böylelikle hem sanal tur üzerinden hem de yerbulduru fotoğrafından istenilen sahneye ulaşım sağlanmış olur.

Tamamlanmış olan sanal tur HTML dosyas1 olarak kaydedilir. $\mathrm{Bu}$ dosya herhangi bir web tarayıcısı kullanılarak, internet bağlantı koşulu aranmaksızın açılabilir ve kullanılabilir.

$\mathrm{Bu}$ yöntem ile elde edilen sanal tur, bir hendek çalışmasının görsel olarak okuyucuya sunulmasına olanak sağlamanın ötesinde hendek verilerinin özellikle yorumlanması aşamasında çok önemli katkılar sağlamaktadır.

$\mathrm{Bu}$ çalışmada geliştirilen Paleosismolojik Üç Boyutlu Sanal Fotoğraflama Yöntemi ile üretilmiş olan sanal tura aşağıdaki linkten ulaşabilirsiniz:

http://jmo.wmv.gen.tr/Panorama.zip

Sanal turu izleyebilmek için aşağıdaki düzende çalışılmalıdır;

- 3D Panorama isimli klasörü açınız,

- Tuzgolu Fault Zone_Yuva (Duru)_2011_Trench isimli firefox HTML Dökümanı'nı Firefox, Google Crome ya da Internet Explorer web tarayıcılarından biriyle "birlikte açınız" (Bunun için farenize sağ tıklayıp birlikte aç seçeneğini seçiniz). Bunun için internet bağlantısı zorunluluğu bulunmamaktadır. Firefox ve Google Crome web tarayıcilarında dosya doğrudan açılır. İnternet Explorer ile açmak istediğinizde "Engellenen içeriğe izin ver" seçeneği ile dosyayı çalıştırabilirsiniz.
- Açılan ekranda sol alt köşede hendeğe ait yer bulduru fotoğrafi görülmektedir. $\mathrm{Bu}$ fotoğraf üzerindeki mavi noktalar, fotoğraflama yapılan noktaları ifade etmektedir. Bu noktalar üzerinden hendek içerisinde istenilen noktaya ulaşılabilir ve o noktada hendeğe ait tüm detay yüksek çözünürlükte incelenebilir. Hendek içerisinde her noktada, fareyi sağa, sola, yukarı, aşağı hareket ettirmek koşuluyla $360^{\circ}$ tur olanağ 1 bulunmaktadır.

- Hendek içerisinde sanal tur yaparken konum değiştirmek için, hendek içerisinde yanıp sönen mavi noktalar veya ekranın sol altındaki yer bulduru fotoğrafı kullanılabilir.

\section{SONUÇLAR}

Bu makalede, paleosismoloji çalışmaları için yeni bir fotoğraflama yöntemi olan "Paleosismolojik Üç Boyutlu Sanal Fotoğraflama Yöntemi” nin uygulama esasları örnek bir hendek çalışması ile tanıtılmıştır.

Yöntemin özellikle derin ve basamaklı paleosismolojik hendek kazılarında başarıyla uygulanabildiği görülmüştür.

Yöntemin sağladığı en önemli avantaj, hendek içerisindeki tüm jeolojik ayrıntının okuyucuya veri kaybı olmaksızın yüksek çözünürlükte aktarılmasıdır. Böylece okuyucuya yorum hakkı tanınabilmektedir.

Paleosismolojik Üç Boyutlu Sanal Fotoğraflama Yöntemi, planlama, fotoğraflama, fotoğrafların birbirine eklenmesi (Stitching) ile sahnelerin oluşturulması ve sahnelerin birleştirmesi ile sanal tur oluşturulması olmak üzere başlıca dört aşamadan oluşmaktadır.

Yöntem sonucunda elde edilen sanal tur, okuyucuya "oradaymış" hissi uyandırarak gezinme olanağı tanımaktadır. 
Yönteminörnekuygulaması, OrtaAnadolu Bölgesi'nin en önemli aktif fay zonlarından biri olan Tuz Gölü Fay Zonu'nun Akhisar-Kılıç Segmenti üzerinde gerçekleştirilmiştir.

Tuz Gölü Fay Zonu (TGFZ), Tuz Gölü kuzeyi ile Kemerhisar (Niğde) arasında uzanan 200 km uzunluğunda, KB-GD doğrultulu, GB’ya eğimli, aktif, sağ yanal doğrultu atım bileşenli normal bir fay zonudur.

TGFZ, uzunlukları 9 ile $33 \mathrm{~km}$ arasında değişen fay segmentlerinden oluşur. Jeolojik fay uzunluğu ve morfotektonik özellikleri nedeniyle Akhisar-Kılıç Segmenti bu zonun en önemli segmentlerinden biridir.

Bu çalışmada, TGFZ'nun Akhisar-Kılıç segmenti üzerinde bir paleosismolojik hendek çalışması yürütülmüştür. Hendek, Duru-2011 Hendeği olarak isimlendirilmiştir.

Duru-2011 Hendeği'nde son 23000 yıl içerisinde üç paleosismik olay (deprem) tanımlanmıştır. $\mathrm{Bu}$ depremlerden ilki (Deprem 3) G.Ö. $29590 \pm 150$ - G.Ö. $16660 \pm 60$ arasında bulunmuştur. Duru-2011 Hendeği'nde tanımlanan ikinci deprem (Deprem 2) G.Ö. $12500 \pm 50$ - G.Ö. $5550 \pm 30$ yılları arasında meydana gelmiştir. Hendekte tanımlanan en güncel depremin (Deprem 1) yaşı ise, G.Ö. G.Ö. $3310 \pm 30$ ile günümüz aralığında bulunmuştur.

Diğer taraftan Kürçer ve Gökten (2012) tarafından Akhisar-Kılıç segmenti üzerinde yürütülen bir başka paleosismolojik hendek çalışmasında (Bağlarkayası-2010 Hendeği) son 10500 yıl içerisinde iki deprem tanımlanmış ve tarihlendirilmiştir. Aynı segment üzerindeki iki hendekten elde edilen deprem verileri fay penceresi yöntemiyle (McCalpin, 1987) değerlendirilmiştir. Buna göre Akhisar-Kılıç Segmenti üzerinde son 23 000 y1l içerisinde 3 deprem meydana gelmiştir. $\mathrm{Bu}$ depremlerden ilki (Deprem 3) G.Ö. $29590 \pm 150$
- G.Ö. $16660 \pm 60$ yılları arasında (yaklaşık G.Ö. 23125 yıl1) meydana gelmiştir. Bu depremden yaklaşık 13095 yıl sonra G.Ö. $10410 \pm 50$ G.Ö. $9650 \pm 50$ yılları arasında (yaklaşık G.Ö. 10 030 y1l1) bir deprem (Deprem 2) daha meydana gelmiştir. Akhisar-Kılıç Segmenti üzerinde tarihlendirilen en güncel deprem (Deprem 1), bir önceki depremden yaklaşı 7690 y1l sonra G.Ö. $3310 \pm 30$ - G.Ö. $1370 \pm 40$ y1lları arasında (yaklaşık G.Ö. 2340 yılı) meydana gelmiştir. $\mathrm{Bu}$ yaş verilerine göre Akhisar-Kılıç Segmenti üzerindeki ortalama deprem tekrarlanma aralığ 10390 yıl olarak önerilmektedir.

Hendeklerde saptanan depremlerde ortalama $35 \mathrm{~cm}$ yer değiştirme miktarları ölçülmüştür. Ortalama deprem tekrarlanma aralığı (10390 yıl) ve her bir depremde meydana gelen ortalama yer değiştirme miktarı $(35 \mathrm{~cm})$ dikkate alınarak yapılan hesaplamada AkhisarKılıç Segmenti üzerindeki yakın dönem (geç Pleyistosen-Holosen) y1llı kayma h1zı 0,034 mm olarak hesaplanmıştır. Bu değer Tuz Gölü Fay Zonu üzerinde Cihanbeyli Formasyonu ve Kızılkaya ignimbiritlerindeki toplam normal eğim atım miktarları ve yaş verileri kullanılarak hesaplanan Pliyosen'den günümüze uzun dönem yıllık kayma hızı (0,046 mm) (Kürçer, 2012) ile yaklaşık uyumludur.

\section{KATKI BELIRTME}

Buçalışma Maden Tetkik Arama Genel Müdürlüğü Jeoloji Etütleri Dairesi Başkanlı̆̆ı'nca yürütülen “Tuz Gölü Fay Zonu'nun Neotektonik Dönem Özellikleri ve Paleosismolojisi, Orta Anadolu, Türkiye” projesi (2010-30-14-02-3) kapsamında gerçekleştirilmiştir. 


\section{EXTENDED SUMMARY}

Paleoseismology is an active tectonic discipline that tries to obtain information about the location, nature, time and magnitude of historical earthquakes by using geological and geomorphological data. Paleoseismic trenching is the most important method that is frequently used in paleoseismology and provides considerable data. One of the most important problems encountered especially in deep and benched paleoseismological trench works is the visual transfer of the geological data appearing on the walls of the trench to the reader. In logging of trench walls; in addition to manual logging technique, which is traditionally applied, photomosaic logging technique also started to be frequently employed in recent years. However, some difficulties are still found in applying photomosaics technique to trench walls, especially in deep and benched trenches.

In this paper, "Paleoseismological Three Dimensional Virtual Photography Method", a new photographic method for paleoseismology, is presented with a case study. This method makes it possible the transfer of all details within the trench to the reader, without any loss of data and with high resolution. Although the method is frequently used in different sectors such as architecture, tourism and museum publicity, it has limited application in earth sciences, especially in paleoseismology.

Paleoseismological Three Dimensional Virtual Photography Method consists of four stages which are respectively: planning, photographing, stitching and constraction of virtual tour. The virtual tour obtained by this method enables to visual material of trench for the reader and provides very important contributions especially in interpretation stage of the trench data. Paleoseismological Three Dimensional Virtual Photography Method has been applied for the first time during the paleoseismological studies carried out on the Tuz Gölü Fault Zone (Central Anatolia, Turkey).

The Tuz Gölü Fault Zone (TGFZ) is one of the most important intra-continental active fault zones of the Central Anatolian Region. TGFZ is an approximately $200 \mathrm{~km}$-long, NW-SE trending, active normal fault zone with a right lateral strike-slip component. The Akhisar-Kılıç segment is one of the most important segments of TGFZ which is composed of fault segments parallel or sub-parallel to each other and with lengths varying between 9 and $33 \mathrm{~km}$. In this study, a paleoseismic trench has been excavated on the middle section of Akhisar-Kllıç segment. Sixteen different microstratigraphic levels were identified within the Duru-2011 Trench. The first four of these levels, which are relatively older, are composed of lava and tuff belonging to Hasandağ volcanism. And the relatively young units are composed of sediments and intercalated volcanic ashes. Totally 9 soil samples from Duru-2011 trench were collected and the radiometric age determination $\left({ }^{14-} C-A M S\right)$ of the samples was carried out at BETA Analytic Lab. (Table 1).

As a result of the evaluation carried out making use of paleoseismological criteria such as trench microstratigraphy, geometry of fault colluvial wedge, upward termination of fault strands, and ${ }^{14} \mathrm{C}$ age data, three paleoseismic events were described within the Duru-2011, which occurred in the last 23000 years. On the other hand, in the last 10500 years two paleoseismic events has been described within the another trench, which was excavated by Kürçer and Gökten (2012). Earthquake data collected from the two trenches on the same segment were evaluated by "fault window method". And averagely earthquake recurrence period of Akhisar-Kılıç segment was calculated as 10390 year. Short time (Late Pleistocene - Recent) annual vertical slip 
rate of Akhisar-Kılıç segment was calculated as 0,034 mm/year. This value is well consistent with long term (Late Pliocene) vertical geological slip rate (0,046 mm-year) of segment.

\section{DEĞİNILEN BELGELER}

Aktuğ, B., Parmaksız, E., Kurt, M., Lenk, O., Kılıçoğlu, A., Gürdal, M. A., Özdemir, S., 2013. Deformation of Central Anatolia: GPS implications: Journal of Geodynamics, v. 67 , no. 0 , p. $78-96$.

Baştanlar, Y., 2005. Parameter extraction and image enhancement for catadioptric omnidirectional cameras. Yüksek Lisans Tezi, O.D.T.Ü. Enformatik Enstitüsü, Ankara.

Baştanlar, Y., Yardımcı, Y., 2005. Hiperbolik Aynalı Katadioptrik Tüm Yönlü Kameralar için Parametre Çıkarımı, IEEE Xplore, http://ieeexplore.ieee.org/stamp/stamp. jsp?arnum ber $=01567669$ (2009.04.20).

Besang, C., Eckhardt, F.J., Harre, W., Kreuzer, G., Müller, P., 1977. Radiometrische Alterbestimmungen an neogenenen Eruptivgesteinen der Turkei. Geologisches Jahrbuch 25, $3-36$.

Çemen, İ., Göncüoğlu, M.C., Dirik, K., 1999. Structural evolution of the Tuzgölü basin in Central Anatolia, Turkey. Journal of Geology, 107, 693-706.

Dirik, K., Göncüoğlu, M.C., 1996. Neotectonic characteristics of Central Anatolia, Int. Geology Review, 38, 807-817.

Dirik, K., Erol, O., 2000. Tuzgölü ve civarının tektonomorfolojik evrimi Orta Anadolu, Türkiye, Haymana-TuzgölüUlukışla Basenleri Uygulamalı Çalışma (Workshop), T.P.J.D. Bülteni, Özel sayı 5.

Dirik, K., 2001. Neotectonic evolution of the northwestward arched segment of the Central Anatolian fault zone, Central Anatolia, Turkey, Geodinamica Acta 14, 147-158.

Dirik, K., Erol, O., 2003. Tectonomorphologic evolution of Tuzgölü and surrounding area, central Anatolia-Turkey. Turkish Association of Petroleum Goelogists Special Publication, $5,27-46$

Dönmez, M., Akçay, A.E., Kara, H., Türkecan, A., Yergök, A.F., Esentürk, K., 2005. Geological maps of Turkey in scale of 1/100 000 Aksaray L 32 sheet. MTA publications, 52, Ankara.

Ergün, B., Şahin, C. 2009. Digital Spherical Photogrammetry Techniques Recently in Use. Harita Dergisi, 142, p. 4050 .
Fraser, J., Pigati, J. S., Hubert-Ferrari, A., Vanneste, K., Avşar, U., Altinok, S., 2009. A 3000-Year Record of GroundRupturing Earthquakes along the Central North Anatolian Fault near Lake Ladik, Turkey: Bulletin of the Seismological Society of America, v. 99, no. 5, p. 26812703 .

Innocenti, F., Mazzuoli, G., Pasquare, F., Radicati Di Brozola, F., Villari, L., 1975. The Neogen calc-alcalin volcanism of Central Anatolia: geochronological data on KayseriNiğde area: Geol. Mag., 112 (4), 349-360.

Koçyiğit, 2000. General neotectonic characteristics and seismicity of Central Anatolia, Haymana-Tuzgölü-Ulukışla basenlerinin uygulamalı çalışması (workshop). Abstracts, 1-26, Aksaray.

Koçyiğit, A., 2005. The Denizli graben-horst system and the eastern limit of western Anatolian continental extension: basin fill, structure, deformational mode, throw amount and episodic evolutionary history, SW Turkey. Geodinamica Acta, 18 (3-4), 167-208.

Koçyiğit, A., Beyhan, A., 1998. A new intracontinental transcurrent structure: the Central Anatolian fault zone, Turkey, Tectonophysics 284, 317-336

Koçyiğit, A., Erol, O., 2001. A tectonic escape structure: Erciyes pull-apart basin, Kayseri, Central Anatolia, Turkey: Geodinamica Acta, 14, 1-13.

Koçyiğit, A., Özacar, A., 2003. Extensional neotectonic regime through the NE edge of the Outer Isparta Angle, SW Turkey: New Field an Seismic Data. Turkish Journal of Earth Sciences, 12, 67-90.

Kürçer, A., 2012. Tuz Gölü Fay Zonu'nun Neotektonik Özellikleri ve Paleosismolojisi, Orta Anadolu, Türkiye. Doktora Tezi (yayınlanmamış), Tez no: 318203, Ankara Üniversitesi, Fen Bilimleri Enstitüsü, 318 sayfa, Ankara, 2012.

Kürçer, A., Gökten, Y.E., 2012. A New Photography Method for Paleoseismological Trenching: "Paleoseismological Three Dimensional Virtual Photography Method", A Case Study: Tuzgölü Fault Zone, Central Anatolia, Turkey, Tectonics - Recent Advances, Evgenii Sharkov (Ed.), ISBN: 978-953-51-0675-3, InTech, Available from: http://www.intechopen.com/books/tectonicsrecent-advances/paleoseismological-three-dimensionalvirtual-photography-method-a-case-study-ba-larkayas2010-trench 
Kwiatek, K., 2005. Generation of a virtual tour in the 3D space applying panoramas, exercised on the sites of Dresden and Cracow. Lisans Tezi, AGH University ofScience and Technology, Dresden.

McCalpin, J. P., 1987. Geological criteria for recognition of individual paleoseismic events in extensional environments. US Geological Survey Open-file Report 87-673, p. 102-114.

McCalpin, J. P. (Ed.), 1996. Paleoseismology, 588 p. Academic Press, New York.

Okay, A.I., Tüysüz, O., Satır, M., Özkan-Altıner, S., Altıner, D., Sherlock, S., Eren, R.H., 2006. Cretaceous and Triassic subduction-accretion, HP/LT metamorphism and continental growth in the Central Pontides, Turkey. Geological Society of America Bulletin, 118: 1247-1269.

Parian, J. A., 2007. Sensor Modeling, Calibration and Point positining with Terrestrial panoramic Cameras. Doctora Thesis, E.T.H. Zurich, Swisszerland.

Reilinger, R.E., Mcclusky, S.C., Vernant, P., Lawrence, S., Ergintav, S., C, akmak, R., Nadariya, M., Hahubia, G., Mahmoud, S., Sakr, K., Arrajehi, A., Paradissis, D., Al-Aydrus, A., Prilepin, M., Guseva, T., Evren, E., Dmitritsa, A., Filikov, S.V., Gomes, F., Al-Ghazzi, R., Karam, G., 2006. GPS constraints on continental deformation in the Africa-Arabia-Eurasia continental collision zone and implications for the dynamics of plate interactions: Journal of Geophysical Research, v. 111, p. V05411, doi: 10.1029/2005JB004051.
Şaroğlu, F., Emre, Ö., Kuşçu, İ., 1992. Türkiye diri fay haritası, MTA, Ankara.

Şengör A.M.C.,1980. Türkiye'nin Neotektoniği’nin Esasları, Türkiye Jeoloji Kurumu Konferans Serisi 2.s.

Şengör, A. M. C., Görür, N., Şaroğlu, F., 1985. Strike-slip faulting and related basin formation in zones of tectonic escape: Turkey as a case study, in Biddle, K. T., and ChristieBlick, N., eds., Strike-slip Deformation, Basin Formation, and Sedimentation, Soc. Econ. Paleontol. Spec. Publ., Volume 37, p. 227-264.

Wells, D.L., Coppersmith, K.J., 1994. New Empirical Relationships among Magnitude, Rupture Length, Rupture Width, Rupture Area, and Surface Displacement. Bulletin of the Seismological Society of America, Vol. 84, No. 4, pp. 974-1002.

$\begin{array}{ll}\text { Makale Geliş Tarihi } & : 11 \text { Eylül } 2013 \\ \text { Kabul Tarihi } & : 18 \text { Aralık } 2013 \\ & : \text { 11 September } 2013 \\ \text { Received } & : 18 \text { December } 2013 \\ \text { Accepted } & \end{array}$

